\title{
PERANAN WAKAF DALAM PEMBANGUNAN EKONOMI DI NEGERI PERAK
}

\section{The Role of Waqf in the Economic Development of Perak}

\author{
Amelia Nur Natasha Nazeri* \\ Asmak Ab Rahman**
}

\begin{abstract}
The role of waqf in economic development is evident in how waqf instruments enable various economic activities. In Perak, Majlis Agama Islam dan Adat Melayu Perak (MAIPk) manages the development of waqfassets byacting as sole trustee in the development of waqf property in that state. This study analyzes the role of waqf in the economic development of Perak. The primary method used to obtain data was through interviews with MAIPk about the management and development of waqf projects. Secondary data was collected through various references such as books, theses and journals. The data thus collected was analyzed using thematic analysis according to the
\end{abstract}

* Master Candidate, Department of Shariah and Economy, Academy of Islamic Studies, University of Malaya, 50603, Kuala Lumpur. natashanazeri@siswa.um.edu.my

** Associate Professor, Department of Shariah and Economy, Academy of Islamic Studies, University of Malaya, 50603, Kuala Lumpur. asmak@um.edu.my 
focus of the study. The study found that waqf played a role in the economic development of Perak's health, education, and the improvement of income and its community's standard of living. The outstanding development in the health sector was the construction of a waqf hemodialysis center. In the educational sector, waqf funds and instruments, contributed to the construction of the Islamic University Sultan Azlan Shah Dormitory (UISAS) and Maahad Tahfiz. Waqf also contributed to improving the income and living standards of the community in Perak through various projects such as the Wakaf Business Centre (WBC) project, waqf housing, and waqf boats to develop the economy of the community in Perak.

Keywords: waqf, Perak, economic development, educational waqf, health waqf

\section{PENDAHULUAN}

Wakaf ialah instrumen yang telah digunakan dalam membangunkan ekonomi sejak zaman para sahabat dan kegemilangan Islam lagi. Contohnya kisah Uthman al-Affan yang menjadikan telaga Raumah sebagai harta wakaf untuk kegunaan masyarakat sekeliling. ${ }^{1}$ Konsep wakaf ini mengamalkan prinsip tolongmenolong dalam kalangan masyarakat dan jika diteliti pemberian tersebut bukanlah kerana mengharapkan balasan ataupun sesuatu daripada manusia bahkan hanya ingin menggapai keredaan Allah SWT. Instrumen wakaf telah digunakan dalam pelbagai sektor seperti pendidikan, kesihatan dan keagamaan. Contohnya aspek pendidikan dengan pembinaan Universiti al-Qurawiyyin di Fez, Morocco hasil daripada tanah wakaf dan manfaatnya itu dapat dinikmati oleh masyarakat pada zaman itu untuk mendapatkan pendidikan yang sewajarnya seperti kelas-kelas agama yang memfokuskan bidang tafsir, hadith dan seterusnya berkembang

Muḥammad Sayyid al-Wakīl, Tarīkh al-Islāmī al-Hạarah alIslāmiyyah (Dimashq: Dār al-Qalam, 1996), 151-152. 
menjadi pusat ilmu kerohanian Islam dan pusat akademi. ${ }^{2}$ Begitu juga dengan sektor kesihatan yang mengaplikasikan alternatif wakaf dengan kewujudan hospital bersalin yang bersumberkan harta wakaf seperti Hospital al-Mansori di Kaherah, Mesir dan kuliyah perubatan Sultan Bayezid II di Edirne, Turki yang berasaskan harta wakaf. ${ }^{3}$

Mekanisme pengagihan semula harta dalam kalangan masyarakat ini seharusnya dikembangkan kerana setiap harta yang khusus untuk masyarakat perlu diketahui perjalanan perkembangan harta itu supaya manfaatnya sentiasa untuk kebaikan dan kesejahteraan masyarakat. Di negeri Perak, berdasarkan Enakmen Wakaf Negeri Perak (2015), Majlis Agama Islam dan Adat Melayu Perak (MAIPk) ialah pemegang amanah tunggal dan institusi yang bertanggungjawab menguruskan aset wakaf. ${ }^{4}$ Jumlah hartanah wakaf di negeri Perak dicatatkan sebanyak 2817 lot tanah wakaf khas dan am yang dibangunkan dengan pelbagai kaedah pembangunan seperti kaedah istibdal, sewaan, pajakan dan usaha sama dengan pihak tertentu untuk memajukan hartaharta wakaf di negeri Perak. ${ }^{5}$ Namun, masih banyak lagi tanah wakaf yang tidak dapat dibangunkan berikutan pelbagai faktor sama ada daripada segi kadar sewaan yang rendah atau cabaran kewangan. Cabaran kewangan daripada sudut ketidakcukupan dana merupakan cabaran utama dalam membangunkan harta wakaf di negeri Perak kerana setiap projek pembangunan terutamanya

2 Siti Mashitoh Mahamood \& Asmak Ab Rahman, "Financing Universities Through Waqf, Pious Endowment: Is It Possible?", Humanomics 31, no. 4 (2015), 432.

3 Heybeli N., "Sultan Bayezid II Külliyesi: One of the Earliest Medical Schools-Founded in 1488," Clinical Orthopaedics and Related Research 467, no. 9 (2009), 2458-2460.

4 Enakmen Wakaf Negeri Perak (2015).

5 Haziq Faris Aris, "Penggunaan Konsep Istibdal Bagi Penyelesaian Pencerobohan Tanah Wakaf Berbentuk Penempatan di Negeri Perak" (Disertasi Sarjana, Universiti Teknologi Malaysia, Johor, 2016), 4. 
projek berimpak besar memerlukan sumber kewangan yang tinggi untuk menampung perbelanjaan projek tersebut. ${ }^{6}$

Pembangunan ekonomi yang lengkap ialah pembangunan yang merangkumi aspek material dan bukan material dan ia boleh diterjemahkan melalui aspek pendidikan, kesihatan, peningkatan pendapatan dan taraf hidup dalam sesebuah masyarakat. Apabila harta-harta wakaf dibangunkan dan menyumbang terhadap aspekaspek berikut ia sekaligus membantu pembangunan ekonomi yang sebenar. $^{7}$ Sehubungan dengan itu, pembangunan harta wakaf sepatutnya meliputi pembangunan dalam aspek-aspek berikut bukan tertumpu kepada aspek keagamaan sahaja supaya ia sentiasa efektif dan efisien kepada masyarakat. Hal ini bertepatan dengan gesaan Sultan Perak Sultan Nazrin Muizzuddin Shah yang menyatakan bahawa semua projek pembangunan harta wakaf hendaklah sentiasa maju dan efektif. ${ }^{8}$

Walaupun negeri Perak juga boleh dikategorikan sebagai negeri yang mempunyai jumlah tanah wakaf yang banyak tetapi kebanyakan tanah wakaf tersebut dibangunkan dengan pembangunan yang bertujuan keagamaan. Contohnya seperti pembinaan masjid, surau dan tanah perkuburan dan perkembangan

$6 \quad$ Nurul Azma Abu Bakar et al., "Kaedah Pembangunan Tanah Wakaf oleh Majlis Agama Islam dan Adat Melayu Perak (MAIPk)," Journal of Islamic, Social, Economics and Development 2, no. 4 (2017), 5; Sanep Ahmad \& Nur Diyana Muhamed, "Institusi Wakaf dan Pembangunan Ekonomi Negara: Kes Pembangunan Tanah Wakaf di Malaysia" (Kertas Kerja, Persidangan Kebangsaan Ekonomi Malaysia ke VI, Ekonomi Berpendapatan Tinggi: Transformasi ke Arah Peningkatan Inovasi, Produktiviti dan Kualiti Hidup, 5-7 Jun 2011); Abdul Hamid Mar Iman \& Muhammad Tahir Sabit Mohamad, Waqf Property: Concept, Management, Development, and Financing (Skudai: UTM Press, 2014).

7 Farhana Mohamad Suhaimi, Asmak Ab Rahman \& Sabitha Marican, "The Role of Share Waqf in the Socio-Economic Development of the Muslim Community," Humanomics 30, no. 3 (2015), 228-229.

8 Noor "Ainon Mohamed Yusof,"Pengendali Organisasi Wakaf Perlu Berkemahiran," laman sesawang Sinar Harian, dicapai pada 12 Jun 2018, http://www.sinarharian.com.my/mobile/edisi/perak/ pengendali-organisasi-wakaf-perlu-berkemahiran-1.506990 
daripada sudut komersil yang kurang. ${ }^{9}$ Kebanyakan MAIN juga menghadapi masalah pembangunan seperti ini yang disebabkan kekurangan kesedaran masyarakat tentang peluasan jenis wakaf dan juga fatwa yang berbeza setiap negeri. ${ }^{10}$ Hakikatnya, wakaf adalah bersifat holistik yang meliputi aspek keagamaan bahkan dapat memberi manfaat kepada pelbagai aspek untuk kesejahteraan masyarakat sekeliling seperti aspek pendidikan, kesihatan dan peningkatan pendapatan dan taraf hidup masyarakat di negeri Perak.

\section{SOROTAN LITERATUR}

Di Malaysia, setiap harta wakaf yang wujud di sesebuah negeri adalah menjadi tanggungjawab dan hak milik Majlis Agama Islam Negeri (MAIN) untuk diuruskan dan dibangunkan. ${ }^{11}$ Justeru, menurut Farhana Suhami dan Asmak Ab Rahman (2017), MAIN adalah institusi yang dipertanggungjawab dan pemegang amanah bagi keseluruhan harta wakaf yang ada di sesebuah kawasan. ${ }^{12}$ Hal ini kerana kuasa undag-undang meletakkan kuasa pengurusan dan pentadbiran harta wakaf adalah berdasarkan kerajaan negeri dan setiap negeri mempunyai sistem pentadbiran wakaf yang berbeza-beza. Perbezaan ini dapat dilihat melalui sebahagian negeri mempunyai perbadanan wakaf yang tersendiri seperti

$9 \quad$ Fidlizan Muhammad et al., "Tahap Kesedaran Masyarakat Islam di Perak Mengenai Wakaf Perak Ar-Ridzuan," Sains Humanika 11, no. 3 (2019), 66-68; Mohd Saharudin Shakrani et al., "Tinjauan IsuIsu Yang Membataskan Penggunaan Wakaf dalam Pembangunan Ekonomi Ummah di Malaysia," Jurnal Syariah 11, no. 2 (2003), 82.

10 Rohayu Abdul Majid \& Rosli Said, "Permasalahan Pengurusan Hartanah Wakaf di Malaysia," International Surveying Research Journal 4, no. 1 (2014), 29-43; Mohd Saharudin Shakrani et al., "Tinjauan Isu-Isu Yang Membataskan Penggunaan Wakaf dalam Pembangunan Ekonomi Ummah di Malaysia," 75.

11 Sharifah Zubaidah S. Ab Kader \& Nor Asiah Mohamed, "Legal Framework for Waqf Land in Malaysia," Shariah Law Reports 4 (2014), 2-3; Rohayu Abdul Majid \& Rosli Said, "Permasalahan Pengurusan Hartanah Wakaf di Malaysia," 31-32.

12 Farhana Mohamad Suhaimi dan Asmak Ab Rahman, "Is Society Willing To Donate To Waqf? Opinions of State Islamic Religious Council in Malaysia," Jurnal Syariah 25, no. 2 (2017), 272. 
negeri Selangor yang mempunya Perbadanan Wakaf Selangor (PWS) manakala sebahagian pula meletakkan tanggungjawab sepenuhnya kepada Majlis Agama seperti negeri Perak yang menjadikan MAIPk sebagai institusi tunggal dalam pengurusan wakaf.

Pengurusan harta wakaf yang berbeza di setiap negeri ini dapat dilihat melalui kajian-kajian seperti kajian Abdul Majid dan Rosli Said yang membincangkan pengurusan wakaf di Kelantan yang dibangunkan oleh MAIK bersama-sama Baitul Mal dan di Selangor melibatkan PWS dalam pentadbiran harta-harta wakaf. Perbandingan dilakukan di antara kedua-dua negeri tersebut daripada sudut isu-isu pembangunan harta wakaf di negeri masing-masing. MAIK berhadapan dengan isu-isu yang berkaitan dengan pengurusan dan pentadbiran harta wakaf tetapi MAIS pula mempunyai isu daripada sudut perundangan dan halangan fizikal harta wakaf. ${ }^{13}$ Begitu juga kajian Shahrina Romli dan yang menjelaskan tentang pelaksanaan wakaf dan keberjayaan dalam pembangunan harta wakaf di negeri-seperti negeri Selangor menjayakan projek-projek wakaf di bawah kelolaan Urus Maju Ehsan (UME) anak syarikat PWS dan projek harta melibatkan 330 buah rumah teres, lot kedai dan bangunan komersial dengan kaedah pajakan selama 99 tahun dan Terengganu yang telah menubukhkan Akademi Kulinari Terengganu melalui kaedah usaha sama (Joint-Venture) di antara Majlis Agama Islam dan Adat Melayu Terengganu (MAIDAM) dan terdapat juga sebuah hotel bertaraf tiga bintang yang berasaskan dana wakaf di bawah nama MAIDAM. ${ }^{14}$ Terdapat juga kajian Nurul Azma yang membicarakan tentang pengurusan wakaf di negeri Perak namun hanya secara ringkas dan sebagai pengenalan. ${ }^{15}$ Nurul Azma menjelaskan bahawa MAIPk ialah pemegang amanah tunggal harta wakaf di

13 Rohayu Abdul Majid \& Rosli Said, "Permasalahan Pengurusan Hartanah Wakaf di Malaysia," 36-41.

14 Shahrina Romli et al., "Pendekatan Semasa Institusi Pengurusan Wakaf dalam Membangunkan Semula Tanah Wakaf di Malaysia," Journal of Law \& Governance 2, no. 1 (2019), 70-73; Zuraidah Mohamed Isa, "A Comparative Study of Waqf Management in Malaysia" 562-563.

15 Nurul Azma Abu Bakar et al., "Kaedah Pembangunan Tanah Wakaf oleh Majlis Agama Islam dan Adat Melayu Perak," 6-7. 
negeri Perak yang pembangunan harta wakaf ini diletakkan di bawah unit khas wakaf dan kajian ini lebih menumpukan kepada kaedah pembangunan harta wakaf yang dijlankan oleh MAIPk seperti istibdal, usaha sama (Joint-venture) dan sebagainya. Oleh itu, dapat diteliti juga bahawa sistem pengurusan daripada sudut organisasi, kaedah kutipan dana wakaf, jumlah harta wakaf di negeri Perak secara terperinci jarang dalam kajian-kajian dan ia memerlukan kajian khusus.

Beralih pula kepada peranan wakaf dalam pembangunan ekonomi, ia telah dibuktikan melalui sejarah sama ada melalui sudut pendidikan, kesihatan, keagamaan dan kegiatan ekonomi. Begitu juga dalam kerangka zaman kini di Malaysia yang merangkumi peranan wakaf dalam setiap aspek sentiasa ada dan berkembang. Dalam ruang lingkup pendidikan, peranan wakaf sudah wujud sejak zaman kegemilangan Islam yang melibatkan penubuhan institusi pendidikan atau operasinya berasaskan sumber wakaf. Hal ini dapat dilihat pada zaman pemerintahan Abbasiyah memperlihatkan institusi pendidikan wakaf dibina iaitu Madrasah Nizamiyah yang menyediakan pelbagai perkhidmatan secara percuma kepada setiap pelajar. ${ }^{16}$

Kajian Ahmad Zaki pula menambah bahawa selain madrasah ini, terdapat banyak lagi institusi pendidikan yang sememangnya berasaskan wakaf seperti Universiti Cordova, Andalusia, AlAzhar, Mesir. ${ }^{17}$ Sehingga kini institusi pendidikan ini masih berdiri teguh dan menghasilkan ribuan cendekiawan yang hebat dalam bidang masing-masing. Universiti Al-Azhar ialah institusi yang mencerminkan keberjayaan wakaf dalam bidang pendidikan

16 Siti Mashitoh Mahamood, Asmak Ab. Rahman \& Azizi Che Seman, "Cabaran Pelaksanaan Wakaf Universiti Awam di Malaysia: Analisis menurut Perundangan di Malaysia," Kanun: Jurnal Undang-undang Malaysia 30, no. 2, (2018), 388-389; Siti Mashitoh Mahamood \& Asmak Ab Rahman, "Financing Universities Through Waqf, Pious Endowment: Is It Possible?" 431-432.

17 Ahmad Zaki Abdul Latiff, Norzaidi Mohd Daud \& Che Zuina Ismail, "Pengurusan Harta Wakaf dan Potensinya ke Arah Kemajuan Pendidikan Umat Islam di Malaysia," Jurnal Pengurusan 2, no. 2 (2008), 25-62; Siti Mashitoh Mahamood \& Asmak Ab Rahman, "Financing Universities Through Waqf, Pious Endowment: Is It Possible?" 431-432. 
yang melibatkan pembiayaan operasi berasaskan dana wakaf dan ia dibincangkan oleh Haslindar Ibrahim dan Mokhthar Ismail. ${ }^{18}$ Begitu juga di Turki dibincangkan oleh Siti Mashitoh Mahamood bahawa Vakif Universiti yang diasaskan melalui dana wakaf telah berkembang sehingga kini dan telah meningkat daripada sudut bilangannya sebanyak 72 buah universiti. Turut tidak ketinggalan di Fez, Morocco yang mempunyai Universiti Al-Qurawiyin sebuah pusat kegiatan ilmu yang masih kukuh sehingga kini dan Universiti Cordova di Spain dibina dan berjalan berasaskan instrumen wakaf. ${ }^{19}$

Di Malaysia pula, wakaf dapat dilihat bahawa peranan wakaf dalam elemen pendidikan lebih banyak terhadap pembinaan sekolah pondok, maahad tahfiz pada peringkat permulaan seperti yang dinyatakan oleh Asmak $\mathrm{Ab}$ Rahman dan peranannya berkembang kepada institut pengajian tinggi menurut Siti Mashitoh Mahamood. ${ }^{20}$ Kajian-kajian tentang keperluan wakaf di institut pendidikan tinggi juga banyak dibincangkan seperti kajian Siti Mashitoh yang menjelaskan model pelaksanaan wakaf di setiap pusat pengajian tinggi dengan penubuhan unit dan pengurusan wakaf di institut pendidikan tinggi masingmasing yang mempunyai struktur pentadbirannya yang sistematik daripada segi platform penerimaan wakaf, organisasi dan gerak kerja sama seperti pengurusan dan pembangunan harta wakaf di negeri-negeri. dan Siti Zakiah Ali membincangkan wakaf di

18 Haslindar Ibrahim et al., "Cash Waqf: An Innovative Instrument for Economic Development," Journal of International Review of Social Sciences and Humanities 6, No. 1 (2013), 2-3; Mokthar Hj Ismail, "Model Operasi Wakaf Pendidikan di Malaysia," 217.

19 Siti Mashitoh Mahamood \& Asmak Ab Rahman, "Financing Universities Through Waqf, Pious Endowment: Is It Possible?" 431; W.K.Mujani et al, "The History of Development of Higher Education Waqf in Malaysia," International Journal of Civil Engineering and Technology (IJCIET) 9, no. 3, (2018), 551-552; Muammer Koç, "Foundation (Awqaf) Universities in Turkey-Past, Present, and Future," (Prosiding, $3^{\text {rd }}$ International Conference on Islam and Higher Education (ICIHE 2012), Kuantan, Pahang, 1-2 Oktober 2012), 4-7.

20 Siti Mashitoh Mahamood, Asmak Ab Rahman et al., "Pembentukan Institusi Pengajian Tinggi Berteraskan Wakaf di Malaysia: Cadangan Model Pelaksanaannya," Jurnal Syariah 26, no. 1 (2018), 6-11. 
Universiti Awam terpilih dalam menampung kos perbelanjaan operasi institusi pendidikan. Dalam pada kajian-kajian tersebut memfokuskan kajian mereka terhadap wakaf di institut pendidikan tinggi, kajian ini akan mengisi jurang terhadap peranan wakaf dalam aspek pendidikan di negeri Perak yang menumpukan terhadap pembinaan asrama pelajar, pembangunan maahad tahfiz yang memerlukan bantuan juga penubuhan dana wakaf khusus untuk pendidikan pelajar-pelajar di peringkat rendah dan menengah.

Peranan instrumen wakaf dalam sektor kesihatan juga banyak dibincangkan dalam kajian-kajian lepas lebih-lebih lagi pada zaman kegemilangan Islam. Kajian Norizah Mohamed membahaskan peranan wakaf yang sangat jelas pada zaman kegemilangan Islam seperti zaman pemerintahan Uthmaniah, Khalifah Al-Walid Ibn Abdul Malik telah mengasaskan hospital pertama di Damsyik berasaskan sumber baitulmal untuk manfaat setiap pesakit tanpa mengira agama dan status. ${ }^{21}$ Selain itu, Ibn Tulun telah membina Hospital Ibn Tulun di Kaherah, Mesir pada tahun 913M yang berhampiran dengan masjid dan keseluruhan kos pembinaannya dibiayai oleh dana wakaf. ${ }^{22}$ Hospital ini adalah bertujuan untuk kepentingan golongan yang kurang berkemampuan. Ernst Herzeld pula membincangkan tentang Hospital Nur al-Din yang dibina pada suatu masa dahulu berasaskan instrumen wakaf. ${ }^{23}$

Dalam kerangka Malaysia, Johor tampil menubuhkan Hospital Waqaf An-Nur yang berjaya yang dibina dan ditadbir menggunakan metode wakaf dan memberi perkhidmatan kesihatan kepada masyarakat. Kajian Norizah Mohamed dan Asmak Ab Rahman dan Ainul Kauthar Ibrahim masing-masing menjelaskan

21 Norizah Mohamed \& Asmak Ab Rahman, "Wakaf Penjagaan Kesihatan: Kajian di Hospital Waqaf An-Nur," Jurnal Syariah 23, no. 3 (2015), 405-406.

22 Norizah Mohamed \& Asmak Ab Rahman, "Wakaf Penjagaan Kesihatan: Kajian di Hospital Waqaf An-Nur," 406; Ainul Kauthar Karim, "Konsep Wakaf Kesihatan \& Perkembangannya di Malaysia" (Proceedings, The Asean Islamic Endownment Seminar 2014 (IQLIMI 2014), Nilai Negeri Sembilan, Malaysia, 29 April 2014), 469.

23 Ernst Herzfeld, "Damascus: Studies in Architecture: I", Ars Islamica 9 (1942), 1-53. 
tentang hospital ini daripada segi kepentingannya kepada sektor kesihatan di Malaysia. ${ }^{24}$ Pembinaan hospital yang asalnya dinaik taraf daripada klinik wakaf ini bertujuan untuk membantu setiap lapisan golongan masyarakat tanpa mengira bangsa, agama dan status dan menurut kajian Ainul Kauthar Ibrahim, ia berjaya membantu masyarakat mendapatkan rawatan dengan kadar bayaran yang rendah sementelah faktor kewangan menyebabkan kebanyakan masyarakat sukar mendapatkan rawatan. ${ }^{25}$ Walaupun peranan wakaf terbukti menyumbang kepada aspek penyediaan klinik dan hospital berasaskan wakaf telah dijelaskan oleh kajiankajian tersebut, kajian tentang pusat hemodialisis yang berasaskan wakaf masih sedikit dibincangkan bahkan pengkhususan kepada wakaf daripada aspek kesihatan di negeri Perak juga tidak banyak diperhalusi dan diteliti.

Di samping tu, wakaf juga merupakan instrumen yang signifikan dalam memberi sumbangan kepada peningkatan ekonomi. Sejak zaman keemasan Islam lagi instrumen wakaf ini telah memberi impak positif terhadap kegiatan ekonomi masyarakat setempat. Kisah Mukhairiq al-Yahudi mewakafkan ladang-ladang kurma supaya dapat dinikmati oleh masyarakat ketika itu jelas menggambarkan peranan wakaf dalam peningkatan ekonomi masyarakat setempat. ${ }^{26}$ Nik Hassan dan Saduman dan Aysun menjelaskan tentang peranan wakaf dalam pembangunan ekonomi zaman Khalifah Uthmaniah kerana ketika itu masyarakat dapat menikmati kemudahan awam yang berasaskan sumber wakaf. $^{27}$

Di Malaysia juga terdapat pelbagai kajian dan tulisan yang membincangkan tentang wakaf dan peranannya dalam peningkatan kegiatan ekonomi. Asmak Ab Rahman telah menghuraikan tentang peranan wakaf yang membuka kepada peluang pekerjaan daripada pembinaan premis perniagaan atau bazar dan pertanian yang membantu meningkatkan ekonomi masyarakat

24 Ainul Kauthar Karim, "Konsep WakafKesihatan \& Perkembangannya di Malaysia," 470.

25 Ibid.

26 Ibn Hisham, Sirah al-Nabawiyah (Mesir: t.pc, t.t.), 12: 38.

27 Saduman, S \& Aysun, E.E., "The Socio-Economic Role of Waqf System in the Cities, Formation and Evolution: Muslim Ottoman Trakia," Journal of Sciences 7, no. 2 (2009), 272-274 
setempat. ${ }^{28}$ Begitu juga dengan Abul Hasan Mohd Sadeq dan Mochammad Arif Budiman yang membahaskan peranan wakaf dalam membasmi kemiskinan dan seterusnya membantu untuk membangunkan ekonomi. ${ }^{29}$ Walau bagaimapun, kajian-kajian ini tidak mengkhususkan peranan wakaf dalam peningkatan ekonomi dan taraf di negeri Perak bahkan ianya secara umum di kebanyakan negeri. Oleh itu, kajian ini mengisi kekosongan daripada sudut penelitian tentang peningkatan pendapatan dan taraf hidup masyarakat di negeri Perak melalui metode wakaf

\section{METODOLOGI KAJIAN}

Kajian ini menganalisis peranan wakaf dalam dalam membangunkan ekonomi masyarakat setempat di negeri Perak dan disebabkan itu ia berfokuskan kepada Majlis Agama Islam dan Adat Melayu Perak (MAIPk) kerana ia ialah agensi utama di negeri Perak yang menguruskan semua perihal yang berkaitan dengan wakaf. Justeru, temu bual menjadi metodologi kajian yang melibatkan MAIPk dan beberapa institusi juga individu penting seperti peniaga di Wakaf Business Centre, dan Persatuan Nelayan Manjung Selatan di negeri Perak. Institusi-institusi penting ini dipilih supaya peranan wakaf dalam aspek pendidikan, kesihatan dan peningkatan pendapatan serta taraf hidup dapat diteliti dengan sebaiknya sementelah mereka memainkan peranan masing-masing. Temu bual dilakukan secara bersemuka dalam bentuk separa berstruktur (separuh piawai) dengan informan dengan mengadakan temujanji terlebih dahulu dan jawapan informan akan direkod menggunakan pita rakaman suara dan tulisan. Dokumen-dokumen penting juga turut diteliti seperti buku kontemporari, kitab-kitab yang berkaitan, artikel, jurnal, enakmen wakaf dan fatwa negerinegeri bagi memastikan data yang tepat dapat diperolehi dalam

28 Asmak Ab Rahman, "Peranan Wakaf dalam Pembangunan Ekonomi Umat Islam dan Aplikasinya di Malaysia," Jurnal Syariah 17, no. 1 (2009), 114-146.

29 Abul Hasan M Sadeq, "Waqf, Perpectual Charity and Poverty Alleviation," International Journal of Social Economics 29 no. 1/2 (2002), 140-148; Mochammad Arif Budiman, "The Significance of Waqf Economic Development (Kertas kerja, MPRA, Politeknik Negeri Banjarmasin, 1 Jun 2014). 
kajian ini. Data-data yang dikumpul itu dianalisis menggunakan metode analisis tematik yang membahagikan peranan wakaf dalam pembangunan ekonomi di negeri Perak kepada tiga tema utama iaitu aspek pendidikan, kesihatan dan peningkatan pendapatan dan taraf hidup. Pembangunan ekonomi dalam kata erti sebenar ialah pembangunan yang melengkapi aspek material dan bukan material dan ini termasuklah kelengkapan daripada aspek keperluan asas masyarakat. Hal ini juga boleh dilihat melalui salah satu indikator pembangunan iaitu Indeks Pembangunan Manusia (HDI) yang mengukur pembangunan melalui tiga aspek penting iaitu jangka hayat, pendidikan, dan taraf hidup individu. Oleh itu, tiga aspek ini dipilih untuk menterjemahkan peranan wakaf dalam pembangunan ekonomi melalui tiga aspek tersebut.

\section{PENGURUSAN WAKAF DI NEGERI PERAK}

Punca kuasa undang-undang diperingkat persekutuan dan negeri telah menetapkan bahawa semua tanggungjawab bagi pengurusan harta-harta wakaf yang ada dipegang oleh Majlis Agama Islam Negeri (MAIN) dan khususnya di negeri Perak MAIPk ialah pemegang amanah tunggal bagi harta-harta wakaf. Hal ini boleh dilihat dalam seksyen 7 Enakmen Pentadbiran Agama Islam (Perak) 2004 yang menjelaskan bahawa MAIN menjadi pemegang amanah tunggal wakaf, nazr dan amanah.

Di negeri Perak, terdapat beberapa agensi yang bertanggungjawab dalam mengendalikan perihal yang berkaitan dengan agama Islam seperti Majlis Agama Islam dan Adat Melayu Perak (MAIPk), Jabatan Agama Islam Perak (JAIPk) dan Jabatan Mufti Negeri Perak. Agensi-agensi ini mempunyai tanggungjawab dan fungsi masing-masing yang berkaitan dengan agama Islam.

Sehubungan dengan itu, segala perihal yang berkaitan dengan harta wakaf dipertanggungjawabkan kepada MAIPk tanpa mempunyai entiti lain yang menguruskan harta wakaf. Hal ini kerana setiap negeri mempunyai enakmen yang berbeza dan hanya sesetengah negeri sahaja seperti negeri Selangor dan Perak 
yang meletakkan enakmen khusus untuk perihal wakaf. ${ }^{30}$ Hal ini dengan kata erti lain, bagi perihal wakaf MAIPk ialah penggubal dan juga pelaksana. Dengan erti kata lain, di negeri Perak, bidang kuasa pengurusan dan pembangunan harta wakaf diletakkan di bawah tanggungjawab MAIPk tanpa mempunyai perbadanan wakaf yang tersendiri dalam membangunkan harta wakaf. Ujar Encik Suhaimi:

“...Basically pengurusan wakaf negeri Perak macam tu lah, diuruskan sepenuhnya oleh Majlis Agama Islam. Kita lah pemegang amanah, kita lah regulator, semua kita... Kita pelaksana, kita semua..." 31

MAIPk yang mempunyai lima unit ${ }^{32}$ penting meletakkan semua perihal pengurusan dan pentadbiran harta wakaf di bawah satu unit yang dikenali sebagai Unit Pengurusan dan Pembangunan Wakaf dan Mal. Unit Pengurusan dan Pembangunan Mal dan Wakaf yang berfungsi menguruskan harta-harta baitulmal dan wakaf diketuai oleh Encik Suhaimi Yusof dan unit ini juga dibahagikan kepada dua bahagian yang saling membantu dalam memastikan pengurusan wakaf berjalan lancar. Unit pertama ialah Unit Pengurusan Hartanah yang diketuai oleh Encik Zulfadli. Skop tugas mereka meliputi pengurusan dan pembangunan aset-aset yang berbentuk tanah seperti tanah wakaf dan bangunan wakaf seperti institusi-institusi Islam; masjid, surau, kubur, maahad tahfiz dan rumah anak yatim untuk perihal penyerahan tanah,

30 Enakmen Pentadbiran Agama Islam (Perak) 2015; Enakmen Wakaf (Negeri Selangor) 2015; Enakmen Wakaf (Terengganu) 2016, Bahagian II menyatakan bahawa Majlis sebagai pemegang amanah tunggal bagi semua wakaf di negeri Terengganu.

31 Suhaimi Yusoff(Pengurus Besar, Unit Pengurusan dan Pembangunan Mal dan Wakaf, Majlis Agama Islam dan Adat Melayu Perak (MAIPk)), dalam temu bual beliau bersama penulis pada 22 Ogos 2019.

32 Lima unit di Majlis Agama Islam dan Adat Melayu Perak (MAIPk) ialah Bahagian Khidmat Pengurusan, Bahagian Agihan Zakat, Bahagian Pengurusan dan Pembangunan Wakaf dan Mal, Bahagian Kewangan, Bahagian Pemasaran dan Pungutan Hasil, dan Bahagian Perhubungan Korporat dan Perancangan Strategik. 
rumah atau masjid untuk diwakafkan. ${ }^{33}$ Bagi unit kedua pula ialah Unit Pengurusan Wakaf yang dikendali oleh Encik Munawwir. Unit ini akan memfokuskan skop kerja mereka terhadap Dana Wakaf Perak Ar-Ridzuan (WPAR) sahaja dan bermaksud semua projek yang berasaskan WPAR diletakkan pengurusannya di bawah Unit Pengurusan Wakaf. ${ }^{34}$

Keseluruhan tanah wakaf yang telah didaftarkan kepada MAIPk sehingga September 2019 ialah lebih kurang 5500 lot tanah. ${ }^{35}$ Sebahagian daripada tanah-tanah wakaf ini telah pun dibangunkan dengan projek institusi keagamaan seperti masjid, kubur, surau dan juga bangunan kediaman yang dibangunkan dengan kaedah saraan kepada institusi-institusi keagamaan. ${ }^{36}$

MAIPk mempelbagaikan cara untuk membangunkan harta wakaf di negeri Perak sama ada daripada sudut pengurusan wakaf dan pembangunan hartanah dan sentiasa memastikan tujuan utama mereka adalah untuk memastikan manfaat wakaf tersebut dapat disalurkan kepada yang berhak secara keseluruhan. Hal ini dibuktikan dengan kata-kata Encik Suhaimi:

"Basically kami Majlis Agama Islam ni bukanlah entiti yang bersifat keuntungan, bukan untuk profit oriented punya organisasi, jadinya pelaksanaan untuk pembangunan tanah-tanah atau aset-aset wakaf yang kita ada banyak dalam bentuk sewaan dan pajakan... tak ada dalam bentuk komersial dan sebagainya..."

Justeru itu, segala projek pembangunan yang dijalankan tidak berfokuskan untuk menjana keuntungan selain hanyalah

33 Zulfadli (Ketua Unit Pengurusan Hartanah, Majlis Agama Islam dan Adat Melayu Perak (MAIPk)), dalam temu bual beliau bersama penulis pada 22 Ogos 2019.

34 Munawwir (Ketua Unit Pengurusan Wakaf, Majlis Agama Islam dan Adat Melayu Perak (MAIPk)), dalam temu bual beliau bersama penulis pada 22 Ogos 2019.

35 Suhaimi Yusoff(Pengurus Besar, Unit Pengurusan dan Pembangunan Mal dan Wakaf, Majlis Agama Islam dan Adat Melayu Perak (MAIPk)), dalam temu bual beliau bersama penulis pada 22 Ogos 2019.

36 Ibid. 
untuk membantu masyarakat Islam keluar daripada kelompok kemiskinan seperti projek Wakaf Business Centre (WBC) untuk peniaga Muslim dan bot wakaf untuk para nelayan Muslim. Tambahan juga, fatwa negeri Perak masih bersifat konservatif yang mengehadkan tanah-tanah wakaf ini dikerjakan dalam bentuk perkara-perkara ibadah sahaja. ${ }^{37}$ Hal ini dibuktikan melalui kebanyakan projek pembangunan harta wakaf melibatkan pembinaan masjid, kubur, dan rumah anak yatim. Disebabkan itu, projek berbentuk pembangunan komersial seperti pembagunan kompleks perniagaan bertemakan wakaf sukar untuk dilaksanakan di negeri Perak. Walaupun begitu, usaha-usaha untuk membangunkan aset wakaf di negeri Perak sentiasa dilaksanakan supaya dapat membantu semua golongan masyarakat Islam.

Bagi memudahkan pengurusan wakaf, sebuah dana juga diasaskan oleh MAIPk dan dana ini berfungsi untuk mengutip dana pembangunan harta wakaf dan membangunkan projekprojek wakaf yang berpotensi. Dana Wakaf Perak Ar-Ridzuan (WPAR) ini ialah dana yang diasaskan bermisikan pemerkasaan institusi wakaf demi kelestarian aset wakaf serta kesejahteraan dan kemajuan ummah. ${ }^{38}$ Dana ini secara umumnya mempunyai tiga komponen asas yang membentuk dana seperti wakaf tunai. Wakaf tunai ini membolehkan masyarakat menyumbang atau berwakaf tanpa dikhususkan kepada mana-mana projek. Kutipan wakaf tunai ini akan digunakan oleh MAIPk untuk masyarakat Islam secara umum ataupun untuk menampung projek-projek di bawah WPAR dalam situasi salah satu projek ini tidak mempunyai dana yang cukup. Komponen kedua pula melibatkan dana yang berasaskan projek. Hal ini di mana dana tersebut berasaskan projekprojek yang telah ditetapkan oleh MAIPk untuk pembangunan aset wakaf. Sumbangan dana oleh masyarakat kepada projek yang dipilih akan diletakkan khusus untuk projek yang dipilih sahaja.

Manakala, bagi komponen ketiga ialah aspek pelaburan yang melibatkan kutipan dengan kerjasama Maybank Islamic. Setiap pelanggan yang mempunyai akaun Maybank dan mereka ingin menyumbang kepada dana WPAR, bank ini akan menambah

37 Ibid.

38 Laporan Tahunan MAIPk 2017. 
setiap ringgit sumbangan mereka. ${ }^{39}$ Contohnya seperti pelanggan A menyumbang RM100 untuk salah satu projek WPAR, Maybank akan menambah RM100 dan menjadikan sumbangan wakaf pelanggan A tadi berjumlah RM200. Hal ini kerana Maybank telah memperuntukkan sebanyak RM5 juta di akaun pelaburan WPAR untuk dilaburkan dan dipadankan dengan sumbangan wakaf pelanggan Maybank. Namun, projek pelaburan dengan kerjasama pihak korporat ini juga mempunyai cabaran daripada segi terhad kepada pelanggan Maybank sahaja dan disebabkan itu perkembangan pelaburan ini agak kurang memberangsangkan dan masih terdapat jumlah baki yang agak besar daripada jumlah RM5 juta yang telah dipadankan. ${ }^{40}$

\section{DAPATAN KAJIAN}

Perbincangan dapatan kajian ini mengklasifikasikan peranan wakaf dalam tiga aspek penting pembangunan ekonomi iaitu aspek pendidikan, kesihatan dan peningkatan pendapatan dan taraf hidup di negeri Perak. Pemilihan ketiga-tiga aspek ini sangat selari dengan Indeks Pembangunan Manusia (HDI) yang di bawah indeks pembangunan ini menekankan tiga aspek yang sama dalam mengukur pembangunan di sesebuah kawasan. Bahkan, jika dilihat ketiga-tiga aspek ini ialah keperluan asas yang diperlukan untuk menjaga kesejahteraan masyarakat negeri Perak dan melalui peranan wakaf dalam aspek-aspek ini akan dapat mengukur pembangunan ekonomi yang sebenar.

\section{Peranan Wakaf dalam Aspek Pendidikan}

Aspek pendidikan ialah aspek tunjang dalam memastikan sesebuah masyarakat mencapai tahap pembangunan ekonomi yang sebenar. Negeri Perak sentiasa berusaha dalam memainkan peranan untuk memberi sumbangan kepada aspek pendidikan terutamanya melalui metode wakaf. Hal ini dapat diterangkan

\footnotetext{
39 Suhaimi Yusoff (Pengurus Besar, Unit Pengurusan dan Pembangunan Mal dan Wakaf, Majlis Agama Islam dan Adat Melayu Perak (MAIPk)), dalam temu bual beliau bersama penulis pada 22 Ogos 2019.

40 Ibid.
} 
melalui rajah di bawah yang meringkaskan tentang metode wakaf yang dikhususkan dalam menyumbang terhadap aspek pendidikan di negeri Perak.

Rajah 1: Peranan Wakaf dalam Aspek Pendidikan di negeri Perak

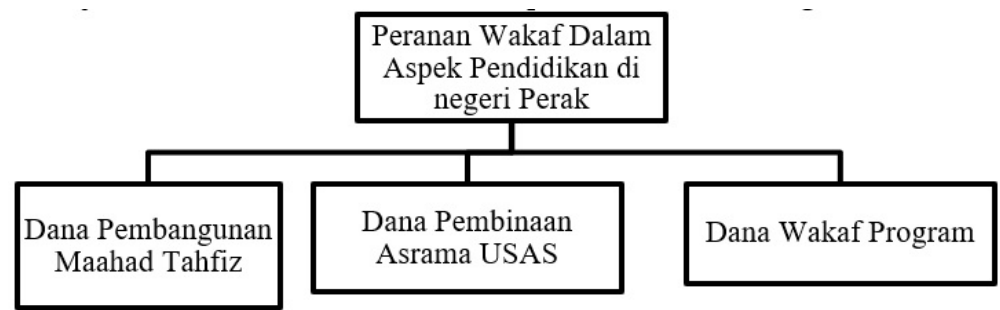

Sumber: Diolah oleh pengkaji berdasarkan hasil temu bual.

Antara metode wakaf yang paling ketara dalam bidang pendidikan ialah apabila MAIPk menjadikan sebahagian tanahtanah wakaf untuk dibina maahad tahfiz dan pondok-pondok agama yang menjadi salah satu sumbangan dalam institusi pendidikan agama. ${ }^{41}$ Bantuan bagi melengkapkan pendidikan maahad tahfiz ini juga sentiasa diberikan. ${ }^{42}$ Hal ini disebabkan antara masalah utama yang dihadapi oleh maahad tahfiz di negeri Perak untuk beroperasi ialah masalah dana yang tidak mencukupi untuk menampung kos penyelenggaraan dan kos operasi.

Secara umumnya, maahad tahfiz ialah institusi pendidikan yang menjadikan pengajian al-Quran sebagai metode utama dalam kurikulum. Pada asalnya, maahad tahfiz mengetengahkan program hafazan 30 juzuk kepada para pelajar sebagai salah satu elemen

41 Suhaimi Yusoff(Pengurus Besar, Unit Pengurusan dan Pembangunan Mal dan Wakaf, Majlis Agama Islam dan Adat Melayu Perak (MAIPk)), dalam temu bual beliau bersama penulis pada 22 Ogos 2019.

42 Ibid. 
penting dalam kurikulum mereka. ${ }^{43}$ Walaupun begitu, berlalunya masa dan teknologi menjadikan sambutan dan permintaan terhadap maahad tahfiz di setiap negeri semakin meningkat kerana metode pengajian mereka yang memberangsangkan dan hal ini menjadikan hafazan para pelajar semakin mantap. ${ }^{44}$

Tambahan pula, sejak tahun 2015, Kurikulum Bersepadu Tahfiz (KBT) telah diwujudkan dengan menggabungkan komponen mata pelajaran tahfiz al-Quran dan sebahagian matapelajaran Kurikulum Standard Sekolah Menengah (KSSM). ${ }^{45}$ Melalui metode ini akan melahirkan para pelajar yang mahir dan efisien daripada sudut profesional dan sudut agama. Hakikatnya, dapat dilihat bahawa pendidikan maahad tahfiz sangat memberikan impak positif kerana melalui pendidikan ini akan melahirkan modal insan yang bukan sahaja bersifat komprehensif bahkan boleh menyumbang kepada pembangunan ekonomi secara keseluruhannya.

Di negeri Perak terdapat banyak maahad tahfiz dan pondok yang dibina sama ada ia dibina di bawah dana kerajaan ataupun persendirian. Mengikut statistik, sehingga tahun 2019 bilangan maahad tahfiz dan pondok agama yang wujud di negeri Perak telah mencecah sebanyak 95 buah sekolah. Bilangan sekolah dan pondok yang banyak ini terutamanya yang dibina oleh individu

43 Nordin Ahmad, "Memperkasa Darul Quran Ke Arah Memartabat Pendidikan Tahfiz di Malaysia" (Kertas kerja, Simposium Pendidikan Tahfiz Nusantara dan Multaqa Huffaz Kali Ke IV, Darul Quran Jakim, Bandar Baru Bangi, Selangor, 1-3 Jun 2015), 2-3; Farah Ilyani Zakaria et al., "Amalan Pembelajaran Pelajar Tahfiz di Institusi Tahfiz Swasta," Jurnal Pendidikan Malaysia SI, no 1 (2018), 141-148.

44 Azmil Hashim \& Misnan Jemali, "Kajian Mengenai Hubungan antara Teknik Pembelajaran Tahfiz dan Pencapaian Hafazan al-Qur'an Para Pelajar," Jurnal Perspektif 6, no. 2 (2015), 15-25; Ashraf Ismail, "Amalan Pengajaran Pensyarah Tahfiz di Maahad Tahfiz al-Quran Kelolaan JAKIM," (Tesis Ijazah Doktor Falsafah, Fakulti Pengajian Islam, Universiti Kebangsaan Malaysia, Bangi, 2018), 30-33.

45 Maklumat Asas Pelaksanaan Kurikulum Bersepadu Tahfiz 2015, laman sesawang Kementerian Pendidikan Malaysia (KPM), dicapai pada 2 Disember 2019, https://www.moe.gov.my/pemberitahuan/ pengumuman/surat-pemakluman-pelaksanaan-dan-maklumat-asasbagi-kurikulum-bersepadu-dini-kbd-dan-kurikulum-bersepadutahfiz-kbt 
persendirian dan Pertubuhan Bukan Kerajaan (NGO) sangat memerlukan bantuan daripada pihak MAIPk. Hal ini kerana kebanyakannya menghadapi pelbagai cabaran dan masalah untuk memastikan keberlangsungan mereka dan antara cabaran berikut ialah masalah kekurangan sumber kewangan untuk menguruskan maahad dan kos-kos penyelenggaraan. Tambahan pula, kebanyakan daripada maahad ini tidak mendapat bantuan daripada kerajaan dan hanya bergantung kepada bantuan daripada orang ramai.

Sehubungan dengan itu, MAIPk mengambil inisiatif untuk menjadikan metode wakaf sebagai usaha untuk membantu maahad tahfiz. Antara usaha yang memberikan impak ialah Dana Pembangunan Maahad Tahfiz yang khusus untuk membantu maahad tahfiz yang memerlukan dana. ${ }^{46}$ Projek dana ini ialah inisiatif MAIPk apabila melihat keperluan maahad-maahad ini untuk memperolehi sumber kewangan. Dana ini berfungsi untuk membantu keperluan fizikal dan prasarana maahad tahfiz yang memerlukan. Walaupun dana ini masih di peringkat permulaan yang beroperasi bermula pada tahun 2019, namun jumlah yang dapat dikutip telah mencapai lebih daripada RM299,000. ${ }^{47}$

Dana Pembangunan maahad tahfiz yang boleh dilihat sebagai projek permulaan akan memulakan sesi agihan kepada maahad tahfiz pada tahun 2020 yang melibatkan sebahagian maahad tahfiz sahaja keran ketidakcukupan dana. MAIPk akan menfokuskan bantuan wakaf kepada maahad tahfiz daripada segi peralatan dan kelengkapan bangunan supaya para pelajar dapat menuntut ilmu dalam keadaan yang selesa dan kondusif. Bagi fokus penyediaan peralatan, ia melibatkan penyediaan keselamatan seperti pemadam api di setiap sekolah dan keperluan pembelajaran seperti katil bagi pelajar yang tinggal di asrama dan kerusi di kelas-kelas yang diperlukan para pelajar. Manakala, kelengkapan bangunan pula akan merangkumi baik pulih struktur bangunan seperti membaiki tandas-tandas yang tersumbat dan penyelenggaraan infrastruktur seperti bumbung sekolah yang tiada siling. Hal ini dibuktikan dengan penjelasan Encik Munawwir:

\section{Ibid.}

47 Laman Sesawang Dana Wakaf Perak Ar-Ridzuan (WPAR), dicapai pada 23 September 2019, http://wakafperak.gov.my/portal/index. $\mathrm{php} / \mathrm{ms} /$ 
“...Sebenarnya dana ni baru lagi buat. Kita nak tambah lagi aspek-aspek wakafyang boleh kita bantu dalam wakaf ni, kita tambah lah dana pembangunan maahad tahfiz ni, so... baru nak mula agih 2020 ni dengan bentuk peralatan dan kelengkapan lah..." 48

Bagi memastikan keperluan maahad tahfiz dapat dipenuhi, MAIPk telah menganalisis dan mengkaji agihan yang efektif bagi memastikan bantuan disalurkan kepada yang berhak. Agihan ini adalah kerjasama daripada sudut data tentang maahad tahfiz daripada JAIPk manakala MAIPk pula akan melakukan kajian lapangan untuk melihatkan keperluan tertinggi bagi mahaadmaahad berikut dan menyediakan sumber kewangan. Melalui data tersebut, pihak MAIPk telah melihat sendiri keadaan hampir 40 maahad tahfiz dan melakukan perbandingan dan analisis akan keperluan tersebut. Hasil daripada kajian lapangan dan data terkumpul, beberapa buah maahad tahfiz yang layak dipilih untuk menerima dana pembangunan tersebut.

Seterusnya, pihak MAIPk akan menetapkan tiga keperluan keutamaan maahad tahfiz dan jumlah kutipan dana yang diserahkan kepada jawatankuasa wakaf untuk bersidang. Contohnya, maahad tahfiz di negeri Perak sangat memerlukan katil, tandas dan perpaipan maka perbincangan dalam kalangan jawatankuasa wakaf tersebut akan menentukan keperluan yang utama untuk diberikan bantuan berdasarkan justifikasi dan dana. Hal ini kerana dana ini masih dalam peringkat permulaan dan hasil yang dikutip juga tidak cukup untuk menampung semua keperluan yang diperlukan oleh Maahad Tahfiz di negeri Perak.

Bagi memastikan agihan dilaksanakan dengan adil dan rukun wakaf terpelihara, MAIPk menetapkan kriteria-kriteria tertentu untuk bantuan tersebut. Antaranya ialah maahad tahfiz tersebut merupakan sekolah yang berdaftar dengan bahagian pendidikan JAIPk. Ini bertujuan untuk melihat jumlah bilangan sebenar maahad tahfiz yang memerlukan bantuan wakaf dan berdasarkan data pendaftaran tersebut, sebanyak 38 buah maahad sahaja yang boleh diklasifikasikan sebagai daif seperti tidak mempunyai katil,

48 Munawwir (Ketua Unit Pengurusan Wakaf, Majlis Agama Islam dan Adat Melayu Perak (MAIPk)), dalam temu bual beliau bersama penulis melalui telefon pada 4 Februari 2020. 
meja dan kerusi yang cukup dan tandas-tandas yang rosak yang perlu dibaiki manakala sebahagian daripada maahad-maahad tersebut pula telah pun lengkap daripada segi peralatan asas. Ujar Encik Munawwir:

"Kita tahu yang maahad tahfiz ni insititusi swasta, tapi tak bermaskud diorang ni bebas buat apa je. So, diorang kenalah didaftarkan di bawah JAIPk supaya bila nak bagi bantuan nanti kita dapat tengok mana je yang perlu sebenarnya..." 49

Kriteria yang seterusnya pula melibatkan tapak binaan maahad tersebut hendaklah di atas tanah milik MAIPk. Apabila bantuan wakaf diberikan kepada maahad yang bukan dibina di atas tanah wakaf, pelbagai isu berbangkit akan timbul seperti wakaf yang tidak mencukupi syarat sah akan diperktikaikan atau sekiranya maahad tersebut dijual atau dipindah milik akan menimbulkan isu pada salah satu rukun wakaf. Apabila maahad-maahad yang dibantu menepati kriteria ini ia akan menjaga kelestarian wakaf secara keseluruhan. Di samping itu, maahad tersebut juga hendaklah mendaftarkan maklumat maahad di Portal Maklumat Pendidikan Islam atau lebih dikenali sebagai sistem Simpeni. ${ }^{50}$ Sistem ini adalah untuk mengetahui bilangan pelajar yang sebenar di setiap maahad tahfiz swasta kerana setiap pelajar maahad mendaftar melalui sistem ini. Hal ini bagi memastikan bantuan dana wakaf yang diberikan menepati bilangan sebenar pelajar maahad. Oleh itu, bantuan wakaf daripada pihak MAIPk adalah berdasarkan bilangan pelajar dalam sistem Simpeni. Apabila dana ini berjaya diagihkan, maahad yang terlibat akan dapat menikmati faedah dana tersebut seterusnya membangunkan sumber manusia yang mahir dalam pelbagai bidang. ${ }^{51}$

Selain itu, MAIPk juga telah mewujudkan dana-dana yang boleh diterjemahkan dalam bentuk program-program pendidikan supaya sedikit sebanyak dapat memberi sumbangan kepada

\section{Ibid.}

50 Laman sesawang Portal Maklumat Pendidikan Islam, dicapai pada 2 Februari 2020, https://simpeni.islam.gov.my/simpeniv2/index.php

51 Munawwir (Ketua Unit Pengurusan Wakaf, Majlis Agama Islam dan Adat Melayu Perak (MAIPk)), dalam temu bual beliau bersama penulis melalui telefon pada 4 Februari 2020. 
pelajar-pelajar yang memerlukan. Antara dana wakaf yang diasaskan untuk projek ini ialah Dana Wakaf Ilmu Program MUMTAZ. ${ }^{52}$ Bilangan kawasan luar bandar yang agak banyak berbanding kawasan bandar di negeri Perak ini menyebabkan wujudnya jurang pendidikan di antara para pelajar kawasan luar bandar. Jurang antara pelajar ini perlu dikurangkan supaya seluruh pelajar di negeri Perak ini mendapat pendidikan yang sempurna dan tiada lagi perbezaan di antara kedua-dua kawasan.

Justeru itu, MAIPk melalui hasil kutipan Dana Wakaf Ilmu Program MUMTAZ menyalurkan bantuan dalam bentuk program yang dilaksanakan khusus bagi pelajar yang bakal menghadapi peperiksaan besar sama ada di peringkat rendah dan menengah. Melalui Dana Pembangunan Ilmu MUMTAZ, pelbagai program dapat dilaksanakan untuk keperluan pembelajaran para pelajar seperti Seminar Kecemerlangan UPSR dan Seminar Jaya SPM. Melalui seminar-seminar ini, para pelajar akan dapat meningkatkan pencapaian pembelajaran mereka dan mendatangkan impak yang positif dalam bidang pendidikan. Oleh itu, MAIPk mensasarkan kutipan untuk memenuhi dana ini sebanyak RM10 juta dan sekiranya ia melebihi target, kutipan masih akan dijalankan supaya lebih banyak lagi program-program pendidikan dapat dilaksanakan dan sehingga kini, kutipan Dana Wakaf Ilmu Program MUMTAZ tersebut telah mencapai sebanyak RM147,464.18

Di samping itu, peranan wakaf juga dapat dilihat apabila MAIPk telah membina bangunan kediaman untuk pelajar-pelajar Universiti Sultan Azlan Shah (UISAS) melalui dana wakaf. Hal ini melihat keperluan UISAS yang kekurangan hostel untuk para pelajar dan menyebabkan para pelajar terpaksa menyewa di luar kawasan kampus dan menanggung bayaran sewa yang tinggi. ${ }^{53}$ Tambahan pula, UISAS ini ialah antara pusat pengajian tinggi yang diasaskan sendiri oleh MAIPk untuk keperluan mahasiswa.

\footnotetext{
52 "Wakaf Ilmu Program Mumtaz", laman sesawang Dana Wakaf Perak Ar-Ridzuan (WPAR), dicapai pada 15 September 2019, http:// wakafperak.gov.my/portal/index.php/ms/projek-wpar/pendidikan

53 Suhaimi Yusoff(Pengurus Besar, Unit Pengurusan dan Pembangunan Mal dan Wakaf, Majlis Agama Islam dan Adat Melayu Perak (MAIPk)), dalam temu bual beliau bersama penulis pada 22 Ogos 2019.
} 
UISAS telah ditubuhkan pada tahun 1999 dan terus berkembang maju dengan penambahan bilangan mahasiswa dan ia telah menimbulkan masalah penempatan pelajar yang memerlukan perharian serius daripada pihak yang bertanggungjawab. ${ }^{54}$ Hanya 1500 orang pelajar sahaja yang mampu ditampung tempat penginapan mereka dan menyebabkan pelajar yang lain terpaksa menyewa di tempat lain.

Isu ini telah dikenal pasti oleh MAIPk dan sekaligus dana asrama UISAS dilancarkan untuk menampung bilangan pelajar yang ramai. Tambahan pula, kini bilangan pelajar di UISAS telah mencecah sebanyak 4000 orang dan ini menunjukkan keperluan yang mendesak terhadap tempat penempatan pelajar. Oleh itu, dana pembinaan UISAS diasaskan dan kutipannya pada tahun 2019 ini, mencecah lebih RM5.5 juta daripada jumlah target RM15 juta. ${ }^{55}$

Memenuhi keperluan supaya pelajar mudah menuntut ilmu, bangunan kediaman pelajar yang pertama telah mula dibina pada bulan Mac 2016 dengan kerja-kerja pembinaan dijalankan oleh Sri Kancil Development Sdn. Bhd. MAIPk telah membiayai pembinaan bangunan ini dengan konsep apartmen lima tingkat sebanyak dua blok yang mempunyai 75 unit dan bangunan yang pertama ini dibina di atas tanah wakaf Lot 14120 Mukim Sayung, Daerah Kuala Kangsar. Bangunan yang dibina bersebelahan dengan UISAS ini lengkap dengan kemudahan dan prasarana yang dapat memberi keselesaan kepada para pelajar dan ia telah menelan kos sebanyak RM13.5 juta pada bulan Disember $2017 .{ }^{56}$ Kos yang banyak ini telah ditanggung sebahagiannya oleh

54 Laman sesawang Universiti Sultan Azlan Shah (UISAS), dicapai pada 15 Oktober 2019, http://www.usas.edu.my/index.php/bm/

55 Laman sesawang Dana Wakaf Perak Ar-Ridzuan (WPAR), dicapai pada 15 Oktober 2019, http://wakafperak.maiamp.gov.my/v1/index. php

56 Muhammad Zulsyamini Sufian Suri, "Asrama USAS RM15 juta siap", laman sesawang Berita Harian, dicapai 3 Januari 2018, https://www.bharian.com.my/berita/pendidikan/2017/10/344669/ asrama-usas-rm15-juta-siap 
Maybank Islamic dan menjadikannya sebagai penyumbang wakaf terbesar untuk pembinaan bangunan kediaman pelajar UISAS. ${ }^{57}$

Projek bangunan kediaman untuk pelajar ini telah pun siap dibina dan didiami oleh para pelajar dan sangat membantu situasi para mahasiswa kerana ia boleh menampung lebih 700 orang pelajar. Kediaman pelajar tersebut diuruskan sepenuhnya oleh UISAS termasuklah daripada aspek kelayakan dan kemasukan pelajar dan ia dibahagikan kepada dua unit yang di hadapannya untuk mahasiswa dan di belakangnya pula untuk mahasiswi. Bagi mengekalkan semangat wakaf sebagai wasilah untuk pembudayaan sifat ta'awun, cas sewaan kepada para pelajar hanyalah pada kadar nominal yang digunakan untuk pengurusan universiti dan penyelenggaraan asrama. Menurut Encik Suhaimi juga:

“...Ya, memang kena cas pada student-student ni... cuma spirit kita cas pada kadar yang lepas pada maintanance dan juga pada cas pengurusan universiti. Takkan nak bagi free kan... maintenance siapa nak bayar..." 58

Malahan, bayaran yang dikenakan untuk setiap pelajar hanyalah RM800 satu semester. Setiap semester yang mempunyai tempoh 6 bulan menjadikan bayaran untuk seorang mahasiswa hanya lebih kurang RM130 sebulan bersama-sama dengan bil utiliti. ${ }^{59}$ Jarak di antara UISAS dan asrama juga sangat dekat bahkan hanya bersebelahan sahaja dan kemudahan seperti kafeteria juga disediakan. ${ }^{60} \mathrm{Hal}$ ini sangat membantu meringankan beban para pelajar melalui kadar sewaan tempat penginapan yang rendah serta memberikan keselesaan dan suasana yang kondusif

57 Suhaimi Yusoff(Pengurus Besar, Unit Pengurusan dan Pembangunan Mal dan Wakaf, Majlis Agama Islam dan Adat Melayu Perak (MAIPk)), dalam temu bual beliau bersama penulis pada 22 Ogos 2019.

58 Ibid.

59 Responden A (Mahasiswi, Universiti Sultan Azlan Shah (UISAS)), dalam temu bual beliau bersama penulis pada 14 Oktober 2019.

60 Kajian lapangan di dua unit bangunan kediaman yang telah dibina oleh MAIPk melalui dana WPAR pada 12 Oktober 2019, jam 12:30 petang. 
Projek ini sentiasa dikembangkan bahkan kini MAIPk dalam proses membina lagi Bangunan Kediaman Pelajar Fasa II untuk kediaman para mahasiswa yang semakin mendesak.

Peranan metode wakaf terhadap sektor pendidikan dilihat apabila MAIPk sentiasa mengesan keperluan dan membangunkan projek dalam bidang pendidikan sama ada melalui program ataupun projek fizikal Pembangunan setiap projek ini sekaligus akan memberi sumbangan kepada bidang pendidikan kerana perancangan bagi setiap projek ini berbentuk jangka masa panjang. Hal ini seterusnya akan menyumbang kepada pembangunan modal insan yang melengkapi definisi pembangunan ekonomi.

\section{Peranan Wakaf dalam Aspek Kesihatan}

Wakaf dan kesihatan ialah aspek yang sangat berkait rapat dan keberjayaan dalam pembinaan institusi kesihatan berasaskan wakaf telah dilaksanakan di kebanyakan kawasan. Antara institusi kesihatan berlandaskan dana wakaf yang ada di Malaysia ialah penubuhan Hospital Waqaf An-Nur yang dikelola oleh negeri Johor. Hospital ini dibina untuk membantu masyarakat sekeliling mendapatkan perkhidmatan kesihatan dengan kadar yang berpatutan dan tidak membebankan yang bertepatan dengan konsep wakaf dalam konsep bantu-membantu. ini. Hal ini kerana apabila individu itu menyumbang kepada dana wakaf untuk membina klinik wakaf atau hospital, mereka yang kurang berkemampuan dapat menikmati perkhidmatan kesihatan yang disediakan dengan kadar yang rendah dan berpatutan. Konsep Hospital Waqaf AnNur ini diperkembangkan lagi dengan penubuhan rangkaian Klinik Waqaf An-Nur dan sehingga tahun 2017 sahaja, Klinik Waqaf An-Nur (KWAN) termasuk Hospital Waqaf An-Nur telah mengembangkan cawangannya yang terdiri daripada 18 buah dan 4 daripadanya berkonsepkan kontena

Di negeri Perak, wakaf menjadi penyumbang kepada aspek kesihatan melalui inisiatif pembinaan pusat hemodialisis wakaf yang berfungsi membantu pesakit dialisis mendapat perkhidmatan 
dialisis dengan kadar yang rendah dan berpatutan. ${ }^{61}$ Walaupun di negeri Perak tiada klinik atau hospital wakaf yang dibina, namun pembinaan pusat haemodialisis yang sedang dijalankan juga boleh diklasifikasikan sebagai projek berimpak positif. Tambahan pula, dana ini baru dilaksanakan pada April 2016 tetapi dapat dilihat manfaat yang menyeluruh yang akan diperolehi dalam tempoh jangka panjang. Tambah Encik Suhaimi lagi, perancangan jangka panjang bagi pembinaan pusat hemodialisis ini diwujudkan di seluruh negeri Perak dan setiap masyarakat Islam baik golongan asnaf ataupun biasa dapat menikmati faedah pusat ini.

“...Perancangan jangka panjang kita kalau boleh nak setiap daerah tu ada pusat hemodialisis wakaf yang bertujuan untuk membantu pesakit-pesakit dialisis yang terpaksa menanggung kos yang tinggi lah." ${ }^{62}$

Perancangan untuk membina pusat hemodialisis ini bermula apabila setiap tahun bilangan pesakit yang menghidapi penyakit masalah buah pinggang di bawah bantuan zakat semakin ramai dan menjadi beban kos kepada MAIPk. Hal ini kerana kos untuk mendapatkan rawatan dialisis bagi setiap pesakit sangat tinggi tambahan lagi jika mereka mendapatkan rawatan di hospital swasta. Kos rawatan bagi khidmat dialisis di hospital swasta menelan sebanyak RM180 hingga RM200 untuk setiap sesi dan menyebabkan ada di antara pesakit ini tidak dapat mendapatkan perkhidmatan dialisis. ${ }^{63}$ Dicatatkan sehingga Jun 2016, lebih 700 orang pesakit yang ditanggung oleh MAIPk dan menjadikan kos yang terpaksa ditanggung oleh MAIPk untuk tempoh 6 bulan

61 "Wakaf Bagi Pembinaan Pusat Hemodialisis Wakaf(Keperluan Dana RM 10 Juta)", Laman Sesawang Dana Wakaf Ar-Ridzuan (WPAR), dicapai pada 7 Oktober 2019, http://wakafperak.maiamp.gov.my/v1/ index.php/projek-wpar/kesihatan

62 Suhaimi Yusoff(Pengurus Besar, Unit Pengurusan dan Pembangunan Mal dan Wakaf, Majlis Agama Islam dan Adat Melayu Perak (MAIPk)), dalam temu bual beliau bersama penulis pada 22 Ogos 2019.

63 Laman Sesawang Perak Today, dicapai pada 15 Oktober 2019, https://peraktoday.com.my/2015/08/maipk-sasar-1-daerah-1-pusatdialisis/ 
untuk rawatan dialisis ialah RM9 juta kerana kos seorang pesakit dialisis melibatkan RM28,680 bererti RM2,390 sebulan. ${ }^{64}$

Jadual 1: Bilangan Penerima Bantuan dan Jumlah Perbelanjaan MAIPk untuk pesakit dialisis daripada tahun 2013 hingga tahun 2016

\begin{tabular}{|c|c|c|}
\hline Tahun & Bil Penerima Bantuan & Jumlah Perbelanjaan (RM) \\
\hline 2013 & 612 & $15,632,859.02$ \\
\hline 2014 & 737 & $21,548,107.15$ \\
\hline 2015 & 729 & $21,784,404.27$ \\
\hline 2016 & 643 & $18,671,975.12$ \\
\hline
\end{tabular}

Sumber: Dipetik dan diubahsuai daripada Laman Sesawang Dana Wakaf Perak Ar-Ridzuan (WPAR) ${ }^{65}$

Sebelum pembinaan pusat hemodialisis ini dilaksanakan, pelbagai perancangan dan kajian telah dilakukan supaya kawasan yang dipilih dapat mendatangkan manfaat kepada masyarakat negeri Perak. Antara faktor-faktor yang diambil kira menurut En Suhaimi dalam pembinaan pusat hemodialisis ini ialah jumlah kepadatan penduduk, perkhidmatan pengangkutan awam dan statistik pesakit yang menghidapi penyakit buah pinggang.

Kalau kita tengok daripada perancangan pembangunan atau mana pemabangunan sekalipun, dia ada kajian (feasibility studies) kan ? so, untuk projek-projek yang di bawah WAPAR ni ada jugak kajian yang kita buat itu tadi kita buat di kawasan yang strategik, maknanya kita ada kawasan tanah wakaf ni di banyak tempat...kawasan pedalaman, kawasan bandar, maknanya kita akan buat kajian... Begitu juga untuk pusat hemodialisis yang kita

64 Laman Sesawang Dana Wakaf Perak Ar-Ridzuan (WPAR), dicapai pada 24 Oktober 2019, http://wakafperak.gov.my/portal/index.php/ $\mathrm{ms} /$ projek-wpar/perkembangan-projek/156-perkembangan-projekwakaf-bagi-pembinaan-pusat-hemodialisis-wakaf

65 Laman sesawang Wakaf Perak Ar-Ridzuan (WPAR), dicapai pada 24 Oktober 2019, http://wakafperak.gov.my/portal/index.php/ms/ projek-wpar/perkembangan-projek/156-perkembangan-projekwakaf-bagi-pembinaan-pusat-hemodialisis-wakaf 
cadang buat di setiap daerah tu, buat masa ni kita tumpu untuk daerah yang bilangan pesakit yang dibiayai doleh zakat paling ramai..." 66

Faktor pemilihan kawasan-kawasan bagi pembinaan pusat hemodialisis ini adalah berdasarkan bilangan pesakit buah pinggang yang ditanggung pembiayaannya oleh zakat supaya apabila pusat hemodialisis selesai dibina, pesakit-pesakit boleh mendapatkan rawatan dialisis di pusat tersebut dan ditanggung oleh dana zakat. Menurut Encik Suhaimi:

“...Maknanya selepas siap pusat hemodialisis ni, pesakit-pesakit yang dibiayai oleh zakat boleh lah nak mendapat rawatan di situ dan dana dia akan ditanggung oleh zakat lah.."

Oleh itu, daerah Manjung dipilih sebagai daerah pertama bagi pembinaan pusat hemodialisis disebabkan mempunyai bilangan pesakit buah pinggang dibiayai oleh sumber zakat yang ramai dan syarat zoning juga telah diluluskan oleh KKM pada tahun $2017 .{ }^{67}$ Pusat hemodialisis yang akan siap dibina ini hasil kerjasama MAIPk dan Pusat Perubatan Ar-Ridzuan dan sebagai permulaan, Pusat Hemodialisis Wakaf ini akan dibina di kawasan Manjung berikutan kawasan yang strategik. Pusat ini akan bertempat di bersebelahan Masjid Alang Iskandar Shah, Kg. Dato Seri Kamaruddin, Manjung dan berkeluasan 584.2 kaki persegi, berkelengkapan dengan kemudahan dan peralatan yang diperlukan. Manakala, kerja-kerja pembinaan pula akan dijalankan

${ }_{66}$ Suhaimi Yusoff(Pengurus Besar, Unit Pengurusan dan Pembangunan Mal dan Wakaf, Majlis Agama Islam dan Adat Melayu Perak (MAIPk)), dalam temu bual beliau bersama penulis pada 22 Ogos 2019.

67 Laman Sesawang Dana Wakaf Perak Ar-Ridzuan (WPAR), dicapai pada 24 Oktober 2019, http://wakafperak.gov.my/portal/index.php/ $\mathrm{ms} /$ projek-wpar/perkembangan-projek/156-perkembangan-projekwakaf-bagi-pembinaan-pusat-hemodialisis-wakaf 
oleh Z.R Construction Sdn. Bhd bermula pada Oktober 2018 dan dijangka akan siap dibina pada bulan Mac 2020. ${ }^{68}$

Pusat hemodialisis ini akan menempatkan sebanyak 12 katil pada permulaan operasi walaupun ia boleh menempatkan 24 katil dan buat permulaan ini juga pusat ini hanya dibuka kepada pesakit yang ditanggung oleh bantuan zakat. Operasi pusat ini masih di peringkat permulaan dan hanya boleh menampung 12 katil sahaja untuk para pesakit dialisis ini. Apabila pusat ini dapat dijalankan dengan kapasiti yang maksimum, pelbagai perancangan akan dilakukan termasuklah menempatkan 24 katil untuk para pesakit dan perkhidmatannya yang akan dibuka kepada keseluruhan masyarakat umum. Ia disokong dengan kenyataan Encik Suhaimi:

“...Dan projek-projek fizikal daripada kluster kesihatan ni iaitu pusat hemodialisis ni masih baru lagi dan buat permulaan ni kita fokuskan kepada asnaf...memang perancangan jangka panjangnya supaya manfaat wakaf ni khususnya pusat hemodialisis ni dapat dinikmati oleh semua orang Islam lah tak kira dari kalangan asnaf ataupun orang biasa lah..." ${ }^{6}$

Usaha MAIPk dalam aspek kesihatan hendaklah dipuji kerana setiap langkah pembinaan pusat hemodialisis ini dirancang dengan teliti. Hal ini kerana setiap nilai yang disumbang diagihkan dengan cermat untuk membina pusat hemodialisis yang dapat membantu menyediakan kemudahan kesihatan. Hubungan yang saling berkait di antara zakat dan wakaf dapat dilihat melalui pusat hemodialisis yang dibina dan peralatannya adalah berasaskan dana wakaf manakala pesakitnya pula yang mendapatkan rawatan di pusat ini pula ialah pesakit yang ditanggung oleh zakat. Rajah di bawah menggambarkan tentang peranan wakaf dan zakat yang saling

68 "Perkembangan Projek Wakaf Bagi Pembinaan Pusat Hemodialisis Wakaf ",Laman sesawang Wakaf Perak Ar-Ridzuan, diapai 25 Disember 2018, http://wakafperak.maiamp.gov.my/v1/index.php/ projek-wpar/perkembangan-projek/194-pw148

69 Suhaimi Yusoff (Pengurus Besar, Unit Pengurusan dan Pembangunan Mal dan Wakaf, Majlis Agama Islam dan Adat Melayu Perak (MAIPk)), dalam temu bual beliau bersama penulis pada 22 Ogos 2019. 
melengkapi antara satu sama lain melalui pusat hemodialisis wakaf ini.

Rajah 2: Wakaf dan Zakat yang saling berperanan untuk membantu Masyarakat Islam

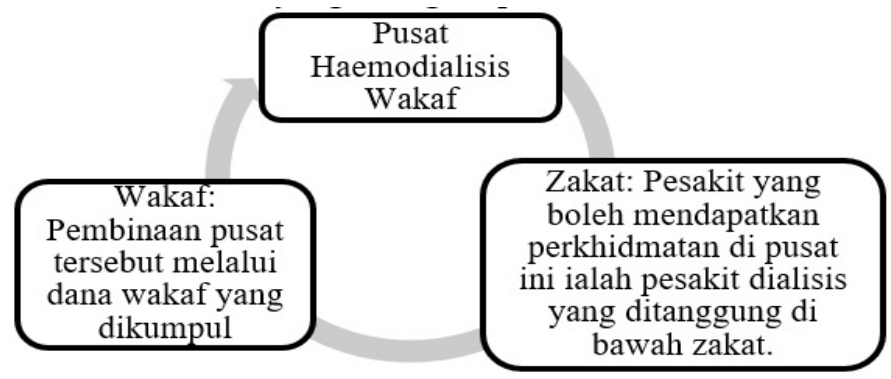

Sumber: Diolah oleh pengkaji berdasarkan hasil temu bual.

\section{Peranan Wakaf dalam Aspek Peningkatan Pendapatan dan Taraf Hidup}

Peningkatan pendapatan dan taraf hidup sering kali dikaitkan dengan kegiatan ekonomi yang berlaku dalam kalangan masyarakat setempat. Justeru itu, kadar kemiskinan dan tahap pendapaan kasar bulanan isi rumah di negeri Perak menjadi kayu ukur bagi peningkatan pendapatan dan taraf hidup. Di negeri Perak, pendapatan kasar bulanan isi rumah berada di tahap yang sederhana dan peratusan kadar kemiskinan juga semakin rendah pada setiap tahun. Bagi meningkatkan lagi pendapatan dan taraf hidup masyarakat setempat pelbagai usaha dilakukan oleh kerajaan negeri seperti program pembasmian kemiskinan yang ditubuhkan pada tahun 2009 iaitu Yayasan Bina Upaya Darul Ridzuan 
$(Y B U)^{70}$ dan projek Agropolitan Ganda di Gerik. ${ }^{71}$ Sehubungan dengan itu, instrumen wakaf juga turut menyumbang kepada aspek peningkatan pendapatan dan taraf hidup di negeri Perak supaya masyarakat Islam khususnya bebas daripada gelombang kemiskinan.

Rajah 3: Peranan Wakaf dalam membantu pembangunan ekonomi masyarakat Islam negeri Perak

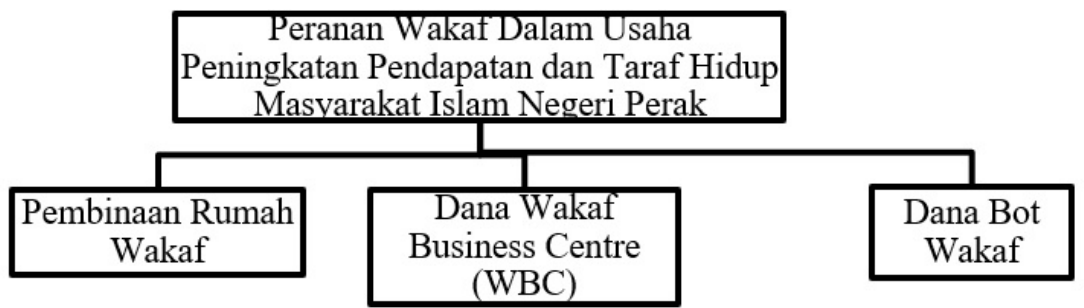

Sumber: Diolah oleh pengkaji berdasarkan hasil temu bual.

Antara usaha wakaf dalam peningkatan pendapatan dan taraf hidup ialah penyediaan rumah kediaman yang disediakan oleh pihak MAIPk adalah dengan cara membina rumah-rumah wakaf untuk disewakan yang dikelolai di bawah Unit Pengurusan Hartanah. Menurut Encik Suhaimi, buat masa ini tiada rancangan untuk mendirikan projek perumahan dibawah dana WPAR tetapi sasaran untuk membina rumah-rumah wakaf di bawah dana ini telah dimasukkan ke dalam pelan jangka panjang. ${ }^{72}$

70 Laman sesawang Yayasan Bina Upaya Darul Ridzuan, dicapai 23 Oktober 2018, http://yayasanbinaupaya.gov.my/

71 "Projek Agropolitan Basmi Kemiskinan Luar Bandar", laman sesawang Suara Perak, dicapai 17 Oktober 2018, http://www. suaraperak.com/projek-agropolitan-basmi-kemiskinan-luar-bandar/; "Perak Terima Anugerah Basmi Kemiskinan", laman sesawang Utusan Melayu, dicapai 28 September 2018, http://ww1.utusan.com. my/utusan/Dalam_Negeri/20140911/dn_12/Perak-terima-anugerahbasmi-kemiskinan

72 Suhaimi Yusoff(Pengurus Besar, Unit Pengurusan dan Pembangunan Mal dan Wakaf, Majlis Agama Islam dan Adat Melayu Perak (MAIPk)), dalam temu bual beliau bersama penulis pada 22 Ogos 2019. 
Rumah-rumah berasaskan wakaf kebanyakannya dibina oleh MAIPk sendiri di atas tanah-tanah wakaf dan terdapat sebahagiannya juga rumah yang diwakafkan oleh individu. Berikutan itu, rumah-rumah wakaf ini lokasinya di seluruh daerah negeri Perak seperti di Taiping, Bagan Serai, dan Ipoh. ${ }^{73}$ Rumah wakaf akan disewa kepada orang Islam yang memerlukan dan sebahagian hasil sewaan tersebut akan diserahkan kepada MAIPk untuk kos pengurusan dan penyelenggaraan. Lebihan daripada hasil sewaan itu akan dikumpulkan untuk membina rumah-rumah wakaf yang lain dengan kadar sewa yang rendah.

Terdapat juga tanah yang telah dirizabkan sebagai tanah wakaf am. Berikutan itu, MAIPk sebagai pemegang amanah tunggal harta-harta wakaf ini menjadikan tanah tersebut sebagai rumahrumah kediaman wakaf. Tanah wakaf ini berkeluasan sebanyak 4,623 meter persegi yang lokasinya terletak di Bandar Tambun, Mukim Ulu Kinta, Daerah Kinta, Perak. Rumah kediaman berasaskan wakaf ini mengenakan sewaan pada kadar yang rendah bagi kegunaan orang Islam di negeri Perak. Keputusan MAIPk dalam membangunkan tanah ini sebagai rumah wakaf memberi kemudahan kepada masyarakat yang memerlukan khususnya masyarakat Muslim yang terpaksa menyewa dalam kadar yang sangat tinggi di kawasan lain. ${ }^{74} \mathrm{Hal}$ ini menunjukkan wakaf berperanan dalam memenuhi keperluan asas yang sangat diperlukan kepada masyarakat untuk meneruskan kehidupan dan meningkatkan taraf hidup

Selain itu, dalam meningkatkan pendapatan dan taraf kehidupan MAIPk juga mengambil langkah untuk mewujudkan peluang pekerjaan kepada masyarakat Islam yang memerlukan. MAIPk telah mewujudkan dana Wakaf Business Centre (WBC) yang dikutip di bawah Dana WPAR. ${ }^{75}$ Dana ini berfungsi untuk

73 Ibid; Zulfadli (Ketua Unit Pengurusan Hartanah, Majlis Agama Islam dan Adat Melayu Perak (MAIPk)), dalam temu bual beliau bersama penulis pada 22 Ogos 2019.

74 Warta Kerajaan Negeri Perak, 2013 (No. 798, 2013) Subseksyen 62(1).

75 "Perkembangan Projek Pembinaan Waqf Business Centre (WBC)", Laman Sesawang Dana Wakaf Perak Ar-Ridzuan (WPAR), dicapai pada 4 Oktober 2019, http://wakafperak.maiamp.gov.my/v1/index. php/projek-wpar/perkembangan-projek/198-pw154 
membina premis perniagaan di seluruh daerah negeri Perak dan premis ini akan memberi peluang kepada peniaga yang layak untuk berniaga di kawasan yang selesa dan kondusif mempunyai fasiliti lengkap seperti berdekatan dengan masjid, tandas, dan mempunyai utiliti lengkap dengan kadar sewa yang sangat nominal. WBC yang merupakan hasil biayaan orang ramai ini akan mengekalkan sewaan kepada para peniaga dan janaan sewaan itu akan dipulangkan manfaatnya kepada orang ramai dengan memperbanyakkan lagi premis perniagaan. Ujar Encik Suhaimi:

"Hmm, since projek ini dibiayai oleh wakaf sumbangan orang ramai, maknanya hasil yang dijana daripada sewaan tu akan kembali kepada dana ni untuk kita wujudkan lebih banyak lagi Wakaf Business Centre (WBC) yang lain lah..."76

Tambahan juga, cas sewaan yang ditetapkan kepada para peniaga ini sangat rendah dan sekadar untuk menampung cas pengurusan. Tujuan MAIPk membina dan menyediakan WBC ini adalah khusus untuk mengeluarkan masyarakat daripada status kemiskinan kerana kebanyakan para peniaga kecil terpaksa berniaga di kawasan yang sangat tidak kondusif dan selesa. Disebabkan itu, pengkhususan premis perniagaan ini adalah untuk para peniaga Muslim walaupun manfaat wakaf secara hukumnya boleh dinikmati oleh semua golongan masyarakat. Menurut Encik Suhaimi:

"Macam Wakaf Business Centre (WBC), peniagapeniaga yang meniaga tepi longkang lah, bawah pokok lah... so kita Wakaf Business Centre (WBC) dan kita panggil dia orang ni meniaga lah di sini dengan kadar yang nominal.. dengan kadar yang diorang mampu dan boleh meniaga dalam keadaan yang baik.. So, satu imej juga la kepada peniagapeniaga orang Islam.. tak ada lah meniaga tepi

76 Suhaimi Yusoff(Pengurus Besar, Unit Pengurusan dan Pembangunan Mal dan Wakaf, Majlis Agama Islam dan Adat Melayu Perak (MAIPk)), dalam temu bual beliau bersama penulis pada 22 Ogos 2019. 


\section{longkang..." 77}

Kajian untuk memilih kawasan yang strategik bagi pembinaan WBC juga dilaksanakan supaya premis tersebut mendapat sambutan masyarakat umum yang sekaligus membantu menambah pendapatan para peniaga tadi. ${ }^{78}$ Sehingga kini, terdapat sebuah WBC yang telah siap dibina dan beroperasi di negeri Perak iaitu WBC di Masjid al-Hidayah, Behrang 2020 yang melibatkan enam buah unit premis perniagaan berkeluasan sebanyak 150 kaki persegi per unit. Premis ini dibina di atas tanah Lot 12293 di Mukim Hulu Bernam Timur, Daerah Muallim, Perak. ${ }^{79}$ Premis ini adalah bersebelahan dengan Masjid al-Hidayah Bandar Behrang 2020 sekaligus mengambil nama tersebut. ${ }^{80}$

Kajian lapangan telah dilakukan di kawasan ini dan terdapat enam unit yang sedang beroperasi dengan disewakan menjadi restoran, kedai runcit, kedai pastri, kedai jahitan dan lainlain. ${ }^{81}$ Unit-unit yang telah disewakan ini telah mula beroperasi sejak 2018 dan ia mendapat sambutan. Menurut Puan Suhaya yang merupakan salah seorang peniaga di situ, WBC ini sangat membantu beliau dalam menjalankan perniagaan di tempat yang kondusif dan sebuah unit WBC ini disewakan dengan bayaran sebanyak RM350 sebulan. Bayaran akan diberikan kepada pihak pengurusan Masjid Al-Hidayah dan MAIPk hanya mengambil 10 peratus sebagai cas penyelenggaraan dan untuk diberi balik manfaat kepada masyarakat Islam.

“...Setakat ni perniagaan yang setahun dengan sewa yang banyak tu alhamdulillah boleh la membantu

77 Suhaimi Yusoff(Pengurus Besar, Unit Pengurusan dan Pembangunan Mal dan Wakaf, Majlis Agama Islam dan Adat Melayu Perak (MAIPk)), dalam temu bual beliau bersama penulis pada 22 Ogos 2019.

78 Ibid.

79 Laman sesawang Dana Wakaf Perak Ar-Ridzuan (WPAR), dicapai 9 Oktober 2018, http://wakafperak.maiamp.gov.my/v1/index.php/en/ wpar-project/progress-of-project/199-pw154

80 Ibid.

81 Kajian lapangan di Wakaf Business Centre (WBC) di Masjid alHidayah Bandar Behrang 2020, Slim River bertarikh 14 Oktober 2019 pada jam 2.30 petang. 
daripada segi pendapatan sebab ramai orang yang datang.." 82

Kadar sewa yang berpatutan ini dibuktikan apabila dibandingkan dengan kadar sewa di sekitar kawasan tersebut. Bagi menyewa premis perniagaan yang serba lengkap, para peniaga perlu membayar kadar sewaan yang dalam anggaran RM2000. ${ }^{83}$ Hal ini akan membebankan para peniaga daripada segi bayaran sewa kepada pemilik premis tersebut. Penulis juga mendapati kadar sewa premis perniagaan yang ada di sekitar WBC ialah dalam anggaran RM1500-2000 dan ia boleh dikategorikan sebagai mahal bagi golongan peniaga yang kurang berkemampuan. Justeru, langkah MAIPk dalam menyediakan WBC akan dapat meringankan beban para peniaga dan seterusnya membantu meningkatkan pendapatan mereka.

Walaupun begitu, penulis mengamati terdapat juga isu berbangkit yang berlaku dalam pengurusan WBC terutamanya melibatkan kadar sewaan. Menurut Encik Muhamed Khairi Ithnin salah seorang peniaga di WBC menjelaskan bahawa kadar sewaan yang dikenakan walaupun berpatutan tetapi masih boleh dikategorikan sebagai kadar sewaan yang mahal berbanding hasil pendapatan bulanan mereka.

"Dulu saya meniaga dekat rumah je takde buat kat kedai pun, baru setahun bukak kedai ni...kadangkadang hasil tu takde la banyak, tapi kalau ikut sesetengah masa tu banyak hasil, So,overall kata alhamdulillah la banyak membantu... Cuma kena rajin lah. Tapi kalau boleh tu sewa kena murah sikit lah kan.." 84

82 Suhaya Abu Hassan (Peniaga/Penyewa Unit Kedai, Wakaf Business Centre (WBC)), dalam temu bual beliau bersama penulis pada 14 Oktober 2019.

83 Salah seorang peniaga yang meyewa sebuah unit Wakaf Business Centre (WBC), Temu bual di WBC Masjid al-Hidayah Bandar Behrang 2020, Slim River bertarikh 1 Oktober 2020 pada jam 12.30 petang.

84 Muhamed Khairi Ithnin (Peniaga/Penyewa Unit Kedai, Wakaf Business Centre (WBC)), dalam temu bual beliau bersama penulis pada 5 November 2019. 
Maka, penulis berpandangan agar MAIPk memantau pihak pengurusan masjid dalam menetapkan kadar sewaan yang berpatutan dan tidak selari dengan hasil pendapatan para peniaga. Walaupun penetapan kadar sewaan ialah pihak pengurusan Masjid namun MAIPk juga hendaklah melakukan pemantauan dan perbincangan dengan pihak pengurusan masjid untuk memastikan kadar sewaan tersebut berada pada kadar yang mampu. Ini kerana tujuan utama WBC ini ditubuhkan adalah mensasarkan golongan yang perlu untuk membantu masyarakat Islam.

Pada tahun 2019 sebuah WBC juga sedang dibina untuk menambah premis perniagaan bagi para peniaga kecil. Projek ini berpandukan WBC yang telah dibina di Bandar Behrang 2020 dan dibina di atas tanah wakaf Lot 95108, Persiaran Pulai Jaya, Bandar Pulai Jaya, Daerah Kinta. Projek ini akan ditampung oleh wakaf sumbangan masyarakat negeri Perak kos keseluruhan berjumlah RM400,000 yang melibatkan dua unit kedai, tiga unit bazar dan 5 kiosk perniagaan. Unit perniagaan tersebut akan merangkumi kedai yang berukuran 10'x20' dan satu unit bazar pula berukuran sebanyak 10'x14' kaki juga sebuah kiosk berukuran 8'x8' kaki setiap sebuah. ${ }^{85}$ Apabila premis perniagaan ini siap dibina, ia membolehkan para peniaga berniaga dalam keadaan yang selesa dan seterusnya menambahkan pendapatan mereka.

Selain itu, MAIPk juga meluaskan usaha untuk membantu meningkatkan pembangunan ekonomi setempat dengan menyediakan bot dan menyewakan kepada nelayan-nelayan yang memerlukan. Projek ini ialah hasil insentif di antara pihak Maybank Islamic dan MAIPk di bawah dana Mywakaf. Mywakaf ialah projek kerjasama di antara enam institusi perbankan Islam dan pihak Majlis Agama Islam Negeri-Negeri dalam projekprojek wakaf dan di negeri Perak membabitkan Maybank Islamic. ${ }^{86}$

85 Laman Sesawang Dana Wakaf Perak Ar-Ridzuan (WPAR), dicapai pada 4 Oktober 2019, http://wakafperak.gov.my/portal/index.php/ $\mathrm{ms} /$ projek-wpar/ekonomi

86 Enam Insitusi Perbankan Islam yang terlibat ialah Affin Islamic, Bank Islam, Bank Muamalat, Bank Rakyat, Maybank Islamic dan Rhb Islamic. Institusi-institusi ini bekerjasama dengan Majlis Agama Islam Negeri dan antara negeri yang terlibat ialah Kedah, Kelantan, Negeri Sembilan, Perak, Perlis, Pulau Pinang, Sarawak, Selangor dan Terengganu. 
Kerjasama ini memfokuskan dana wakaf tersebut kepada empat aspek utama ekonomi iaitu pendidikan, pembangunan ekonomi, kesihatan dan pelaburan. Disebabkan itu, di negeri Perak projek bot wakaf menjadi inisiatif pertama di Malaysia dan menjadi projek berimpak besar dalam memajukan sosioekonomi masyarakat setempat. $^{87}$

Pelaksanaan program pembinaan bot dan program penyewaan bot berkenaan kepadan nelayan Muslim adalah disebabkan insiden kemiskinan yang berlaku di negeri Perak melibatkan sebahagian golongan nelayan. Menurut Puan Amirah Liya, keadaan kemiskinan dalam kalangan nelayan ini dapat dilihat melalui hasil tangkapan atau hasil pendapatan mereka tergolong dalam golongan miskin di bawah sistem e-kasih.

"Kita di pihak Lembaga Kemajuan Ikan Malaysia (LKIM) sendiri, sebab persatuan nelayan ni bawah LKIM lah dia punya skop tu sebagai penyalur bantuan kepada golongan sasar iaitu nelayan. Jadi bila kata bantuan ni untuk orang yang memerlukan lah. Memang ada lah keadaan kemiskinan tu sebab kalau kita tengok range hasil tangkapan tu memang B40 punya range..." 88

Kebanyakan para nelayan ini terdiri dalam kalangan golongan B40 yang pendapatan mereka sekitar RM3,000 dan ke bawah. Kebanyakan mereka mempunyai kemahiran tetapi tidak memiliki bot yang sesuai untuk ke laut dalam dan hanya boleh menangkap ikan di sekitar pesisir pantai sahaja sekitar lingkungan satu batu nautika daripada pantai sekaligus menyebabkan hasil tangkapan dan pendapatan tidak begitu memberangsangkan. Oleh itu, MAIPk berperanan untuk membantu meningkatkan pendapatan mereka

87 "Maybank Islamic Partners MAIPk Improve Perak Socioeconomy", laman sesawang New Straight Times, dicapai 31 Disember 2019, https://www.nst.com.my/business/2018/01/322026/maybankislamic-partners-maipk-improve-perak-socio-economy; http://www. mywakaf.com.my/ms/our-projects/?project=1

88 Amirah Liya Zainal Abidin (Pengurus Besar, Persatuan Nelayan Manjung Selatan), dalam temu bual beliau bersama penulis pada 23 Oktober 2019. 
dengan menyediakan dana bagi pembinaan bot yang boleh pergi ke laut tengah sehingga dua ke lima batu nautika supaya dapat membantu untuk menambah sumber pendapatan dan sekaligus membaiki taraf hidup dalam kalangan nelayan di negeri Perak. Ujar Encik Suhaimi:

“...Wakaf bot tu kita sasarkan kepada nelayannelayan yang di pesisir pantai yang ada keupayaan untuk mengendalikan bot ke laut tengah ni... dan lebih menyedihkan lagi nelayan kita ni hanya main tepi-tepi pesisir pantai je dalam lingkungan 1 batu nautika daripada pantai. Maksudnya, dengan ramainya bilangan nelayan pesisir pantai ni dengan sumber ikan yang terhad, so, pendapatan dia orang tak banyak..." 89

Projek ini mengekalkan kaedah yang sama seperti projek hostel Universiti Islam Sultan Azlan Shah (UISAS) dengan penyewaan bot-bot tersebut yang telah siap dibina kepada pengendali bot yang akan menyewakannya kepada awak-awak yang terdiri daripada golongan miskin. ${ }^{90}$ Hasil sewaan tersebut akan diserahkan kepada MAIPk bagi tujuan pengurusan manakala selebihnya akan digunakan untuk membuat bot-bot baru supaya lebih banyak bot dapat disewakan dan dapat membantu para nelayan di negeri Perak secara keseluruhannya. Encik Suhaimi menjelaskan:

“...Dia bayar sewa dan sewaan dia tu akan pergi ke dua akaun. Satu akaun WAPAR untuk kita wujudkan bot-bot yang lain, satu lagi akaun maintainance. So, ktia dapat bantu satu; dapat mewujudkan bot-bot yang lain lagi, satu lagi dapt membantu pengendali bot dan awak-awak dia ni yang terdiri daripada orang miskin sekeliling..." 91

89 Suhaimi Yusoff(Pengurus Besar, Unit Pengurusan dan Pembangunan Mal dan Wakaf, Majlis Agama Islam dan Adat Melayu Perak (MAIPk)), dalam temu bual beliau bersama penulis pada 22 Ogos 2019.

90 Awak-awak ialah para pekerja dalam bot yang diupah oleh nelayan untuk membantu menangkap ikan.

91 Ibid. 
Pembinaan bot wakaf ini adalah hasil kerjasama dengan UniKL-Met setelah konsultasi bersama-sama Jabatan Perikanan. Setelah kedua-dua institusi mencapai kata sepakat, MAIPk menyerahkan projek ini kepada UniKL-Met untuk pembinaan bot tersebut. Pembinaan bot wakaf dijalankan dan diserahkan kepada Persatuan Nelayan Manjung Selatan untuk disewakan kepada ahli-ahlinya. ${ }^{92}$ Pembinaan bot wakaf yang bernilai RM160,876.20 ini mempunyai ukuran saiz 30 kaki panjang 8 kaki lebar serta dilengkapi dengan enjin bot $115 \mathrm{hp}$ dan $40 \mathrm{hp}$, pukat, garmin, teknologi GPS, ecosounder dan marine robot membolehkan para nelayan meneroka kawasan laut dalam dan seterusnya meningkatkan hasil tangkapan. ${ }^{93}$

Setelah bot diserahkan kepada Persatuan Nelayan Manjung Selatan, pihak persatuan akan mencari penyewa yang berkelayakan untuk mengoperasikan bot wakaf tersebut. Nelayan yang benar-benar layak mengikut syarat yang telah ditetapkan MAIPk seperti hendaklah Islam serta berada dalam pangkalan data e-kasih yang menjadi syarat kelayakan untuk menyewa bot tersebut. Para nelayan di kawasan sekitar boleh memohon untuk menyewa bot-bot wakaf yang ada tetapi pemilihan penyewa bagi tujuan pengoperasian adalah berdasarkan keputusan mesyuarat ahli lembaga pengarah. ${ }^{94}$

Program bot wakaf merupakan projek perintis dan setakat ini melibatkan sebuah bot dan seorang penyewa. Bot tersebut disewakan daripada Persatuan Nelayan kepada nelayan terpilih dengan kadar yang sangat nominal iaitu total RM1,200 yang dipecahkan kepada RM200 sebagai kos pengurusan, RM500 sumbangan balik kepada MAIPk dan RM500 untuk

92 "Majlis Penyerahan Bot Waqaf Perak Ar-Ridzuan oleh UniKL MIMET Kepada MAIPk", laman sesawang Majlis Agama Islam \& Adat Melayu Perak (MAIPk), dicapai 20 Oktober 2018, http:// www.maiamp.gov.my/maiamp2/index.php/info/berita/1037-majlispenyerahan-bot-waqaf-perak-ar-ridzuan-oleh-unikl-mimet-kepadamaipk.html

93 Ibid

94 Amirah Liya Zainal Abidin (Pengurus Besar, Persatuan Nelayan Manjung Selatan), dalam temu bual beliau bersama penulis pada 23 Oktober 2019. 
tabung penyelenggaraan. ${ }^{95}$ Bayaran balik kepada MAIPk ini bukanlah berbentuk keuntungan semata-mata bahkan bertujuan menggandakan lagi bilangan bot wakaf supaya lebih ramai nelayan boleh menyewa bot-bot wakaf. Pada hakikatnya, program bot wakaf ini sangat membantu seseorang nelayan kerana dengan kadar sewaan yang berpatutan, nelayan mendapat sebuah bot berjumlah untuk dioperasikan. Berikutan itu, usaha MAIPk ini sangat perlu dipuji kerana memberi inisiatif kepada nelayan Muslim yang kurang berkemampuan untuk mengoperasikan bot dan menambahkan hasil pendapatan mereka. Hal ini disokong oleh kenyataan Puan Amirah Liya:

“...Tapi memang sangat membantu lah. Sebab apa sekarang ni kalau nelayan siapa yang nak bagi sebijik bot yang nilai dia kata secara keseluruhan di RM100,000, dapat sebijik bot, dapat pukat, dapat enjin... Nelayan terima ni kena bersyukur sebab orang lain ni nak ni..." 96

Dengan adanya bot wakaf ini penyewa bot tadi boleh membantu awak-awak lain dengan mengambil mereka bekerja disebabkan dahulunya para nelayan tidak memiliki bot dan mereka terpaksa bekerja dengan pengendali bot lain. Melalui projek bot wakaf, nelayan Muslim boleh mengoperasikan bot dan pada masa yang sama membantu pekerja yang lain pula untuk menambah hasil pendapatan dan ia sangat selari dengan konsep tolong-menolong dalam instrumen wakaf. Hal ini disokong dengan kenyataan Puan Amirah Liya dan Encik Suhaimi:

“...Cuma dia (nelayan) tu dan dia dapat lah daripada segi peningkatan pendapatan pembantu dia...krukru dia yang dia boleh ambik awak-awak yang lain bekerja dengan dia..." 97

“...Satu lagi dapt membantu pengendali bot dan awak-awak dia ni yang terdiri daripada orang miskin

95 Ibid.

96 Ibid.

97 Amirah Liya Zainal Abidin (Pengurus Besar, Persatuan Nelayan Manjung Selatan), dalam temu bual beliau bersama penulis pada 23 Oktober 2019. 
sekeliling..." 98

Sehingga tahun 2019, nelayan yang menyewa bot wakaf ini meraih pendapatan secara purata berjumlah RM3,000 sebulan. Walaupun hasil tangkapan nelayan ini adalah mengikut musim namun usaha bot wakaf ini sangat membantu nelayan. Bahkan, jika terdapat lebih banyak bot wakaf yang disewakan kepada nelayannelayan, hal ini akan dapat membantu nelayan dengan lebih luas. Pendapatan nelayan tersebut dilihat dalam jadual di bawah dan ia masih dalam proses perkembangan disebabkan projek yang masih lagi dalam tempoh percubaan. Walaupun begitu, boleh dilihat perkembangan hasil pendapatan nelayan dalam keadaan yang memberangsangkan. Hal ini disokong oleh Puan Amirah Liya yang menjelaskan pada tahun 2019, program bot wakaf ini sudah boleh dikatakan mempunyai 50 peratus peningkatan secara kasar dalam membantu nelayan tersebut menambah pendapatan.

"Tapi daripada segi peningkatan pendapatan memang meningkat lah. Sebab berbeza tau kalau sebelum ni diorang ni awak-awak je, pembantu nelayan...awak-awak ni pulak dapat berapa percent je daripada hasil tangkapan, yang ni dia dapat full satu bot.."

Jadual 2: Jumlah pendapatan nelayan yang menyewa bot wakaf bermula bulan Januari hingga September 2019

\begin{tabular}{|c|c|}
\hline Bulan & $\begin{array}{c}\text { Jumlah Pendapatan Kasar } \\
\text { (RM) }\end{array}$ \\
\hline Januari & RM 3,416.00 \\
\hline Februari & RM 7,209.55 \\
Mac & RM 3,414.50 \\
April & RM 2,639.05 \\
Mei & RM 2,602.55 \\
Jun & RM 2,924.35
\end{tabular}

98 Suhaimi Yusoff(Pengurus Besar, Unit Pengurusan dan Pembangunan Mal dan Wakaf, Majlis Agama Islam dan Adat Melayu Perak (MAIPk)), dalam temu bual beliau bersama penulis pada 22 Ogos 2019. 


\begin{tabular}{cc} 
Julai & RM 3,468.95 \\
Ogos & RM 3,998.40 \\
September & RM 3,207.40 \\
\hline Jumlah & RM 32,880.75 \\
\hline
\end{tabular}

Sumber: Berdasarkan temu bual bersama responden kajian. ${ }^{99}$

Peningkatan dalam pendapatan nelayan membuktikan usaha MAIPk memberi kesan positif terhadap pembangunan ekonomi nelayan. Oleh itu, usaha untuk membina lagi bot-bot wakaf diperlukan agar taraf hidup nelayan dapat diperbaiki dan seterusnya membantu meningkatkan ekonomi nelayan-nelayan di negeri Perak. Disebabkan itu, dapat dilihat bahawa dana pembinaan bot wakaf akan sentiasa dikutip bagi membantu usaha MAIPk untuk membina bot wakaf tercapai. Berikutan itu, sehingga kini dana yang berjaya dikutip ialah sebanyak RM90,324.35 daripada target kutipan RM5 juta. ${ }^{100}$

Setiap usaha MAIPk dalam memperbaiki taraf hidup masyarakat melalui metode wakafini akan membantu pertumbuhan ekonomi masyarakat negeri Perak. Hal ini kerana setiap projek yang diketengahkan dapat membuka peluang pekerjaan serta menambahkan pendapatan dalam kalangan orang Islam di negeri Perak.

\section{KESIMPULAN}

Perkaitan wakaf dan pembangunan ekonomi sangat tidak boleh disangkal dan ia jelas memainkan peranan penting dan menyumbang kepada ekonomi masyarakat di negeri Perak. Hal ini boleh dilihat sama ada melalui aspek pendidikan, kesihatan dan peningkatan pendapatan dan taraf hidup masyarakat. Peranan wakaf dalam aspek pendidikan boleh dilihat melalui penyediaan Dana Wakaf Ilmu MUMTAZ, pembangunan Maahad-Maahad

\footnotetext{
99 Amirah Liya Zainal Abidin (Pengurus Besar, Persatuan Nelayan Manjung Selatan), dalam temu bual beliau bersama penulis pada 23 Oktober 2019.

100 Laman Sesawang Dana Wakaf Perak Ar-Ridzuan (WPAR), dicapai pada 4 Oktober 2019, http://wakafperak.gov.my/portal/index.php/
} 
Tahfiz, dan pembinaan asrama UISAS. Manakala, daripada aspek kesihatan pula, wakaf berperanan dalam menyediakan pusat hemodialisis yang berasaskan dana wakaf. Pusat hemodialisis wakaf yang bakal siap ini akan sangat membantu pesakit buah pinggang di negeri Perak mendapatkan rawatan dengan kadar yang rendah dan berpatutan sekaligus memperlihatkan peranan wakaf dalam penyediaan institusi kesihatan. Begitu juga peranan wakaf dalam penyediaan rumah wakaf, penyediaan bot berasaskan wakaf dan Wakaf Business Centre (WBC) yang menyumbang dalam aspek peningkatan pendapatan dan taraf hidup dalam kalangan masyarakat negeri Perak. Namun, cadangan penambahbaikan perlu sentiasa dilaksanakan supaya pengurusan aset wakaf di negeri Perak dapat berjalan lancar dan efektif seperti mempergiatkan kutipan dana wakaf di negeri Perak dan memperbaiki agihan wakaf di negeri Perak. Ini kerana walaupun wakaf memperlihatkan peranannya dalam membangunkan ekonomi setempat di negeri Perak, ia masih boleh dipertingkatkan supaya manfaat wakaf dapat dieksploitasi sepenuhnya.

\section{RUJUKAN}

"Perkembangan Projek Pembinaan Waqf Business Centre (WBC)", Laman Sesawang Dana Wakaf Perak Ar-Ridzuan (WPAR), dicapai pada 4 Oktober 2019, http://wakafperak. maiamp.gov.my/v1/index.php/projek-wpar/perkembanganprojek/198-pw154

"Wakaf Bagi Pembinaan Pusat Hemodialisis Wakaf (Keperluan Dana RM 10 Juta)", Laman Sesawang Dana Wakaf ArRidzuan (WPAR), dicapai pada 7 Oktober 2019, http:// wakafperak.maiamp.gov.my/v1/index.php/projek-wpar/ kesihatan

Abdul Hamid Mar Iman \& Muhammad Tahir Sabit Mohamad. Waqf Property: Concept, Management, Development, and Financing. Skudai: UTM Press, 2014.

Ahmad Zaki Abdul Latiff, Norzaidi Mohd Daud \& Che Zuina Ismail. "Pengurusan Harta Wakaf dan Potensinya ke Arah Kemajuan Pendidikan Umat Islam di Malaysia." Jurnal Pengurusan 2, no. 2 (2008), 25-62. 
Ainul Kauthar Karim. "Konsep Wakaf Kesihatan \& Perkembangannya di Malaysia." Proceedings, The Asean Islamic Endownment Seminar 2014 (IQLIMI 2014), Nilai Negeri Sembilan, Malaysia, 29 April 2014.

Ashraf Ismail. "Amalan Pengajaran Pensyarah Tahfiz di Maahad Tahfiz al-Quran Kelolaan JAKIM." Tesis Ijazah Doktor Falsafah, Fakulti Pengajian Islam, Universiti Kebangsaan Malaysia, Bangi, 2018.

Asmak Ab Rahman. "Peranan Wakaf dalam Pembangunan Ekonomi Umat Islam dan Aplikasinya di Malaysia." Jurnal Syariah 17, no. 1 (2009), 113-152.

Azmil Hashim \& Misnan Jemali. "Kajian Mengenai Hubungan antara Teknik Pembelajaran Tahfiz dan Pencapaian Hafazan al-Qur'an Para Pelajar," Jurnal Perspektif 6, no. 2 (2015), $15-25$.

Ernst Herzfeld. "Damascus: Studies in Architecture: I." Ars Islamica 9 (1942), 1-53.

Farah Ilyani Zakaria et al. "Amalan Pembelajaran Pelajar Tahfiz di Institusi Tahfiz Swasta." Jurnal Pendidikan Malaysia SI, no 1 (2018), 141-148.

Farhana Mohamad Suhaimi dan Asmak Ab Rahman. "Is Society Willing To Donate To Waqf? Opinions of State Islamic Religious Council in Malaysia." Jurnal Syariah 25, no. 2 (2017), 271-273.

Farhana Mohamad Suhaimi, Asmak Ab Rahman \& Sabitha Marican. "The Role of Share Waqf in the Socio-Economic Development of the Muslim Community." Humanomics 30, no. 3 (2015), 228-229.

Fidlizan Muhammad et al. "Tahap Kesedaran Masyarakat Islam di Perak Mengenai Wakaf Perak Ar-Ridzuan." Sains Humanika 11, no. 3 (2019), 63-69.

Heybeli N. "Sultan Bayezid II Külliyesi: One of the Earliest Medical Schools-Founded in 1488." Clinical Orthopaedics and Related Research 467, no. 9 (2009), 2458-2460.

Laman Sesawang Dana Wakaf Perak Ar-Ridzuan (WPAR), dicapai pada 15 Oktober 2019, http://wakafperak.maiamp. gov.my/v1/index.php 
Laman Sesawang Dana Wakaf Perak Ar-Ridzuan (WPAR), dicapai pada 23 September 2019, http://wakafperak.gov.my/portal/ index.php/ms/

Laman Sesawang Universiti Sultan Azlan Shah (UISAS), dicapai pada 15 Oktober 2019, http://www.usas.edu.my/index.php/ $\mathrm{bm} /$

Mohd Saharudin Shakrani et al. "Tinjauan Isu-Isu Yang Membataskan Penggunaan Wakaf dalam Pembangunan Ekonomi Ummah di Malaysia." Jurnal Syariah 11, no. 2 (2003), 73-98.

Muhammad Sayyid al-Wakīl, Tarīkh al-Islāmī al-Hadarah alIslāmiyyah. Dimashq: Dār al-Qalam, 1996.

Muhammad Zulsyamini Sufian Suri, "Asrama USAS RM15 juta siap", laman sesawang Berita Harian, dicapai 3 Januari 2018, https://www.bharian.com.my/berita/ pendidikan/2017/10/344669/asrama-usas-rm15-juta-siap

Nordin Ahmad. "Memperkasa Darul Quran Ke Arah Memartabat Pendidikan Tahfiz di Malaysia.” Kertas kerja, Simposium Pendidikan Tahfiz Nusantara dan Multaqa Huffaz Kali Ke IV, Darul Quran Jakim, Bandar Baru Bangi, Selangor, 1-3 Jun 2015.

Norizah Mohamed \& Asmak Ab Rahman. "Wakaf Penjagaan Kesihatan: Kajian di Hospital Waqaf An-Nur." Jurnal Syariah 23, no. 3 (2015), 405-406.

Nurul Azma Abu Bakar et al. "Kaedah Pembangunan Tanah Wakaf oleh Majlis Agama Islam dan Adat Melayu Perak." Journal of Islamic, Social, Economics and Development 2, no. 4 (2017), 1-10.

Rohayu Abdul Majid \& Rosli Said. "Permasalahan Pengurusan Hartanah Wakaf di Malaysia." International Surveying Research Journal 4, no. 1 (2014), 29-43.

Saduman, S \& Aysun, E.E. "The Socio-Economic Role of Waqf System in the Cities, Formation and Evolution: Muslim Ottoman Trakia." Journal of Sciences 7, no. 2 (2009), 272274. 
Sanep Ahmad \& Nur Diyana Muhamed. "Institusi Wakaf dan Pembangunan Ekonomi Negara: Kes Pembangunan Tanah Wakaf di Malaysia." Kertas Kerja, Persidangan Kebangsaan Ekonomi Malaysia ke VI, Ekonomi Berpendapatan Tinggi: Transformasi ke Arah Peningkatan Inovasi, Produktiviti dan Kualiti Hidup, 5-7 Jun 2011.

Shahrina Romli et al. "Pendekatan Semasa Institusi Pengurusan Wakaf Membangunkan Semula Tanah Wakaf di Malaysia." Journal of Law \& Governance 2, no. 1 (2019), 66-79.

Sharifah Zubaidah S. Ab Kader \& Nor Asiah Mohamed. "Legal Framework for Waqf Land in Malaysia." Shariah Law Reports 4 (2014), 2-3.

Siti Mashitoh Mahamood \& Asmak Ab Rahman, "Financing Universities Through Waqf, Pious Endowment: Is It Possible?", Humanomics 31, no. 4 (2015), 430-453.

Siti Mashitoh Mahamood, Asmak Ab Rahman et al. "Pembentukan Institusi Pengajian Tinggi Berteraskan Wakaf di Malaysia: Cadangan Model Pelaksanaannya." Jurnal Syariah 26, no. 1 (2018), 1-22.

Siti Mashitoh Mahamood, Asmak Ab. Rahman \& Azizi Che Seman. "Cabaran Pelaksanaan Wakaf Universiti Awam di Malaysia: Analisis menurut Perundangan di Malaysia." Kanun: Jurnal Undang-undang Malaysia 30, no. 2 (2018), 183-185.

\section{Temu bual}

Amirah Liya Zainal Abidin (Pengurus Besar, Persatuan Nelayan Manjung Selatan), dalam temu bual beliau bersama penulis pada 23 Oktober 2019.

Muhamed Khairi Ithnin (Peniaga/Penyewa Unit Kedai, Wakaf Business Centre (WBC)), dalam temu bual beliau bersama penulis pada 5 November 2019.

Munawwir (Ketua Unit Pengurusan Wakaf, Majlis Agama Islam dan Adat Melayu Perak (MAIPk)), dalam temu bual beliau bersama penulis pada 22 Ogos 2019. 
Responden A (Mahasiswi, Universiti Sultan Azlan Shah (UISAS)), dalam temu bual beliau bersama penulis pada 14 Oktober 2019.

Suhaimi Yusoff (Pengurus Besar, Unit Pengurusan dan Pembangunan Mal dan Wakaf, Majlis Agama Islam dan Adat Melayu Perak (MAIPk)), dalam temu bual beliau bersama penulis pada 22 Ogos 2019.

Suhaya Abu Hassan (Peniaga/Penyewa Unit Kedai, Wakaf Business Centre (WBC)), dalam temu bual beliau bersama penulis pada 14 Oktober 2019.

Zulfadli (Ketua Unit Pengurusan Hartanah, Majlis Agama Islam dan Adat Melayu Perak (MAIPk)), dalam temu bual beliau bersama penulis pada 22 Ogos 2019. 
Jurnal Fiqh, Vol. 18 No. 1 (2021) 169-216 